\title{
Pengaruh Penggunaan Media Pembelajaran Terhadap Hasil Belajar Dasar-Dasar Kelistrikan (DDK) Kelas X Program Keahlian Teknik Instalasi Tenaga Listrik (TITL) SMK Negeri 1 Lubuk Pakam
}

\author{
Muhammad Hanif ${ }^{1}$, Dra. Pintauli Saragih., M.Pd ${ }^{2)}$ \\ Pendidikan Teknik Elektro Fakultas Teknik \\ Universitas Negeri Medan \\ muhammadhanifsikumbang@ rocketmail.com
}

\begin{abstract}
ABSTRAK
Penelitian ini bertujuan untuk mengetahui hasil belajar Dasar-Dasar Kelistrikan yang diajar dengan menggunakan Media Pembelajaran Crocodile dan yang diajar dengan menggunakan media pembelajaran gambar di papan tulis pada siswa kelas X SMK Negeri 1 Lubuk Pakam Tahun Ajaran 2014.

Media Pembelajaran yang digunakan adalah media crocodile yang mana dalam pelaksanaan diadakan perlakuan kepada kelompok-kelompok eksperimen. Populasi dalam penelitian ini adalah siswa kelas X SMK Negeri 1 Lubuk pakam yang mengikuti sub kompetensi Dasar-Dasar Kelistrikan yang terdiri dari 2 kelas, satu kelas, diajar dengan media crocodile (kelas eksperimen) dan satu kelas lagi diajar dengan menggunakan media gambar dipapan tulis (kelas kontrol). Jumlah sampel tiap kelas sebanyak 30 dan 35 orang, jadi jumlah sampel seluruhnya sebanyak 65 orang.

Perlakuan dilakukan selama 3 minggu atau sebanyak 3 kali pertemuan tatap muka untuk masingmasing kelas. Perlakukan yang diberikan berdasarkan pada Rencana Pelaksanaan Pembelajaran yang telah disiapkan oleh peneliti. Pada akhir pertemuan, kedua kelas penelitian diberi Posttes untuk melihat hasil belajar siswa. Berdasarkan hasil tes inilah dapat diketahui sejauh mana pengaruh yang terjadi pada siswa.

Dari hasil analisis data dengan tingkat penerimaan pada taraf signifikansi 5\% menunjukkan bahwa hasil belajar siswa yang diajar menggunakan media crocodile lebih tinggi dari hasil belajar siswa yang diajar dengan menggunakan media gambar dipapan tulis, dimana $t_{\text {hitung }}>t_{\text {tabel, }}$ yaitu 4,004 $>$ 1,67035. Dari perhitungan diperoleh $\mathrm{F}_{\text {hitung }}<\mathrm{F}_{\text {tabel }}(1,24<1,74)$ sehingga diperoleh kesimpulan bahwa sampel berasal dari populasi yang homogen. Dengan kata lain Hasil belajar siswa yang diajarkan dengan menggunakan media crocodile lebih tinggi dari hasil belajar siswa yang diajarkan dengan menggunakan media gambar dipapan tulis.
\end{abstract}

\section{PENDAHULUAN}

\section{A. Latar Belakang Masalah}

Peranan media saat ini menjadi peranan penting khususnya di dunia pendidikan. Media merupakan suatu alat teknologi yang dapat membantu dalam melakukan kegiatan terutama di bidang pendidikan. Musfiqon (2012:28) mendefinisikan media pembelajaran sebagai alat bantu berupa fisik maupun nonfisik yang sengaja digunakan sebagai alat perantara antara guru dan siswa dalam memahami materi pembelajaran agar lebih efektif dan efisien.

Namun kenyataannya, dari hasil observasi peneliti di SMK Negeri 1 Lubuk Pakam, guru belum menggunakan media pembelajaran dalam kegiatan belajar mengajar. J. Pasaribu, selaku ketua jurusan mengatakan bahwa media yang dipakai dalam kegiatan belajar mengajar yaitu media gambar papan tulis. Dimana guru menjelaskan materi pembelajaran melalui media papan tulis. Sehingga kegiatan belajar mengajar siswa didalam kelas menjadi monoton dan tidak terjadi interaksi antara siswa dan murid sehingga keaktifan siswa tidak muncul.

Rendahnya prestasi belajar yang dialami
siswa dikarenakan pemilihan media
pembelajaran yang kurang tepat sehingga
keaktifan siswa dalam kegiatan belajar mengajar
kurang. Untuk itu peneliti melakukan penelitian
dengan menggunakan media pembelajaran
Crocodile Teknologi. Media Pembelajaran
Crocodile Technology 609 adalah software
untuk pembuatan rangkaian dan layout
elektronika dalam 3D. Sebelumnya sudah
pernah ada Crocodile clip namun bedanya
adalah yang terbaru ini menampilkan visual


grafis seakan akan benda yang kita rangkai itu sudah dapat kita rasakan. Dan tidak hanya dirasakan tapi bisa kita simulasikan.

Kelebihan fitur Crocodile Technology 609 adalah:

1. Memiliki tampilan tools bar untuk mempermudah presentasi.

2. Memiliki komponen elektronika yang biasa kita pakai sehari hari.

3. Dapat merangkai layout, merancang PLC, dan memiliki keluaran suara.

4. Menampilkan Lampu LED persis seperti aslinya

5. Memudahkan kita dalam teknik pengontrolan motor.

6. Memiliki banyak layout yang bisa digunakan, terutama yang bersifat open source yang tersedia luas di internet.

Untuk Pembelajaran Dasar-Dasar kelistrikan, Media Crocodile merupakan software pembelajaran berbentuk simulasi yang menempatkan siswa pada keterlibatannya di dalam proses belajar mengajar dan siswa lebih aktif serta dapat menghubungkan pengetahuan yang dimiliki dan penerapannya dalam kehidupan sehari-hari. Di dalam media ini sudah terdapat komponen-komponen seperti komponen elektronika pasif. Misalnya pada Mata pelajaran DDK terdapat materi mengenai Rangkaian Seri, di dalam Media Crocodile ini siswa sudah dapat merakit rangkaian yang diinginkan dan merubah serta mengetahui nilai dari rangkaian tersebut. Dan di media ini juga siswa dapat mengetahui jalur dari rangkaian yang dibuat tersebut.

Eddi M. Sukisno (2013) tentang implementasi media crocodile physic yang berkesimpulan bahwa crocodile physic merupakan media simulasi, media ini memberikan gambaran simulasi. Pada materi listrik dinamis, siswa dapat melihat bagaimana simulasi rangkaian listrik digunakan. Pada pembelajaran dikelas eksperimen, siswa diberikan bagaimana rangkaian dibentuk, bagaimana alur rangkaian dibuat.

Untuk itu peneliti mengadakan suatu penelitian yang nantinya berguna bagi pendidikan khususnya kalangan Sekolah Menengah Kejuruan (SMK). Dalam hal ini yang akan diteliti adalah Pengaruh Penggunaan Media Pembelajaran terhadap Hasil Belajar Dasar-Dasar Kelistrikan (DDK) Kelas X Program Keahlian Teknik Instalasi Tenaga Listrik di SMK Negeri 1 Lubuk Pakam Tahun Ajaran 2013/2014.

\section{B. Identifikasi Masalah}

Dari latar belakang yang dikemukakan diatas dapat diidentifikasi beberapa masalah, yaitu:

1. Penggunaan Media Pembelajaran yang dilakukan disekolah untuk meningkatkan hasil belajar Dasar-dasar Kelistrikan (DDK) di SMK Negri 1 Lubuk Pakam belum maksimal.

2. Hasil belajar siswa pada mata pelajaran DDK di SMK Negri 1 Lubuk Pakam masih dibawah nilai kelulusan yaitu 70 .

3. Tingkat pemahaman siswa dalam penguasaan materi pembelajaran Dasar-dasar Kelistrikan masih kurang.

4. Kurangnya penggunaan media pembelajaran yang dapat merangsang siswa untuk aktif dalam belajar.

5. Minat siswa dalam proses belajar mengajar masih kurang.

\section{Batasan Masalah}

Melihat dari identifikasi masalah dalam penelitian ini maka masalah difokuskan pada penerapan media pembelajaran yaitu Penggunaan media pembelajaran Crocodile untuk meningkatkan Hasil Belajar Siswa pada kompetensi DDK kelas X Program Keahlian Teknik Instalasi Tenaga Listrik di SMK Negeri 1 Lubuk Pakam Tahun Ajaran 2013/2014.

\section{Rumusan Masalah}

Berdasarkan uraian latar belakang masalah, identifikasi masalah dan batasan masalah penelitian, maka rumusan masalah yang dikemukakan dalam penelitian ini adalah:

1. Bagaimana hasil belajar pada kompetensi Dasar-dasar Kelistrikan (DDK) dengan menggunakan media pembelajaran crocodile pada siswa kelas X Program Keahlian Teknik Instalasi Tenaga Listrik SMK Negeri 1 Lubuk Pakam Tahun Ajaran 2013/2014?

2. Bagaimana hasil belajar pada kompetensi Dasar-dasar Kelistrikan (DDK) dengan menggunakan media gambar papan tulis pada siswa kelas X Program Keahlian Teknik Instalasi Tenaga Listrik SMK Negeri 1 Lubuk Pakam Tahun Ajaran 2013/2014?

3. Apakah hasil belajar siswa pada kompetensi Dasar-dasar Kelistrikan (DDK) yang diajarkan dengan menggunakan media pembelajaran crocodile lebih tinggi daripada siswa yang diajarkan dengan menggunakan media gambar papan tulis kelas X Program Keahlian Teknik Instalasi Tenaga Listrik SMK Negeri 1 Lubuk Pakam Tahun Ajaran 2013/2014?

\section{E. Tujuan Penelitian}

Sesuai dengan permasalahan yang akan diteliti, maka tujuan penelitian ini adalah: 
Pengaruh Penggunaan Media Pembelajaran Terhadap Hasil Belajar Dasar-Dasar Kelistrikan (DDK) Kelas X Program Keahlian Teknik Instalasi Tenaga Listrik (TITL) SMK Negeri 1 Lubuk Pakam

1. Untuk mengetahui hasil belajar pada kompetensi Dasar-dasar Kelistrikan (DDK) dengan menggunakan media pembelajaran crocodile pada siswa kelas X Program Keahlian Teknik Instalasi Tenaga Listrik SMK Negeri 1 Lubuk Pakam Tahun Ajaran 2013/2014.

2. Untuk mengetahui hasil belajar pada kompetensi Dasar-dasar Kelistrikan (DDK) dengan menggunakan media gambar papan tulis pada siswa kelas X Program Keahlian Teknik Instalasi Tenaga Listrik SMK Negeri 1 Lubuk Pakam Tahun Ajaran 2013/2014.

3. Untuk mengetahui hasil belajar siswa pada kompetensi Dasar-dasar Kelistrikan (DDK) yang diajarkan dengan menggunakan media pembelajaran crocodile lebih tinggi daripada siswa yang diajarkan dengan menggunakan media gambar papan tulis kelas X Program Keahlian Teknik Instalasi Tenaga Listrik SMK Negeri 1 Lubuk Pakam Tahun Ajaran 2013/2014.

\section{F. Manfaat Penelitian}

Dari Hasil Penelitian ini diharapkan bermanfaat kepada berbagai pihak, antara lain yaitu:

\section{Bagi Sekolah}

Sebagai bahan referensi bagi sekolah untuk meningkatkan keterampilan mengajar guru dengan menggunakan media pembelajaran khususnya pada mata pelajaran DDK (Dasardasar Kelistrikan).

\section{Bagi Guru dan Siswa}

Dapat menggunakan media pembelajaran crocodile dalam proses belajar mengajar, khususnya pada materi DDK (Dasar-dasar Kelistrikan). Dan Siswa ikut terlibat secara langsung pada proses pembelajaran.

\section{Bagi Peneliti}

Sebagai masukan bagi peneliti dalam kemampuan untuk menggunakan media pembelajaran untuk meningkatkan hasil belajar siswa.

4. Bagi Jurusan Pendidikan Teknik

Elektro

Informasi bagi jurusan untuk bahan kajian tentang media pembelajaran.

\section{BAB II \\ TINJAUAN TEORI}

\section{A. Kerangka Teoritis}

\subsection{Hakikat Belajar}

Belajar adalah proses perubahan tingkah laku (Sanjaya, 2009:55). Dan menurut Sanjaya proses belajar adalah terus-menerus, yang tidak pernah berhenti dan tidak terbatas pada dinding kelas (2009:108). Demikian juga hal ini dipertegas oleh Arsyad, Azhar (2007:1) yang menyatakan belajar adalah suatu proses yang kompleks yang terjadi pada diri setiap orang sepanjang hidupnya. Proses belajar itu terjadi karena adanya interaksi antara seseorang dengan lingkungannya. Oleh karena itu dapat terjadi kapan saja dan dimana saja.

Dari penjelasan diatas, banyak orang yang mengemukakan pendapat tentang pengertian belajar.

a. Belajar sebagai suatu proses yang membuat seseorang mengalami perubahan tingkah laku sebagai hasil dari pengalaman yang diperolehnya (Gage dan Berliner dalam Dimyati dan mudjiono, 2006:116).

b. Sanjaya (2012:112) bahwa belajar adalah proses mental yang terjadi di dalam diri seseorang, sehingga menyebabkan munculnya perubahan tingkah laku.

c. Hamzah Uno dan Nurdin Mohamad (2012:139) bahwa belajar diartikan sebagai suatu proses perubahan tingkah laku sebagai hasil dari latihan pengalaman individu akibat interaksi dengan lingkungannya.

d. Belajar ialah suatu proses usaha yang dilakukan individu untuk memperoleh suatu perubahan tingkah laku yang baru secara keseluruhan, sebagai hasil pengalaman individu itu sendiri dalam interaksi dengan lingkungan (Slameto, 2003:02)

e. Moh. Surya dalam Hamzah Uno \& Nurdin Mohamad (2012:139) menerangkan bahwa belajar dapat diartikan sebagai suau proses yang dilakukan oleh individu untuk memperoleh perubahan perilaku baru secara keseluruhan, sebagai hasil dari pengalaman individu itu sendiri dalam berinteraksi dengan lingkungannya.

Dari beberapa defenisi diatas disimpulkan bahwa hakikat belajar adalah proses perubahan dari yang tidak tahu menjadi tahu yang bersifat positif dan membangun bagi diri pribadi atau suatu proses kegiatan yang dilakukan agar menuju ke arah yang lebih baik lagi, sehingga menghilangkan tanda tanya yang ada dalam pikiran.

\subsection{Hasil Belajar}

Hasil belajar dapat didefenisikan sebagai kemampuan yang diperoleh seseorang setelah melalui kegiatan belajar serta perubahan tingkah laku seseorang.

Keller dalam Abdurrahman (2003), hasil belajar adalah proses aktual yang ditampilkan oleh anak sedangkan usaha adalah perbuatan yang terarah pada penyelesaian tugas-tugas belajar. Dengan demikian hasil belajar dipengaruhi oleh besarnya usaha yang dicurahkan, intelegensi, kesempatan yang 
diberikan kepada anak untuk mengembangkan dirinya, yang pada akhirnya akan mempengaruhi terhadap hasil belajar.

Hasil belajar menunjukkan tingkat kemampuan siswa dalam mengikuti sebuah proses pembelajaran. Winkel (1996) menggolongkan kemampuan sebagai hasil belajar menjadi kemampuan kognitif, kemampuan afektif dan kemampuan psikomotorik.

Benjamin S. Bloom (dalam Mulyono, 2003:38) ada tiga ranah (domain) hasil belajar, yaitu kognitif, afektif dan psikomotorik, Taksonomi Bloom membagi sasaran hasil belajar menjadi 3 ranah yaitu :

\section{a. Ranah Kognitif}

Ranah kognitif berhubung dengan kemampuan berpikir/nalar. Dalam taksonomi Bloom dikenal 6 jenjang ranah kognitif yaitu: (1). Pengetahuan, aspek kognitif yang paling rendah tetapi paling mendasar. Dengan pengetahuan individu dapat mengenal dan mengingat kembali suatu objek, ide, prosedur, konsep, definisi, nama, peristiwa, tahun, daftar, rumus, teori, atau kesimpulan. Hendaknya diperhatikan bahwa cirri pokok tingkatan ini ialah ingatan, (2). Pemahaman, merupakan kegiatan mental intelektual yang mengorganisasikan materi yang diketahui. Temuan-temuan yang didapat dari mengetahui sepertii definisi, informasi, peristiwa, fakta disusun kembali dalam struktur kognitif yang ada, (3). Penerapan, menggunakan pengetahuan untuk memecahkan masalah atau menerapkan pengetahuan dalam kehidupan sehari-hari, (4). Analisis, menentukan bagian bagain dari suatu masalah dan menunjukkan hubungan antara bagian tersebut, melihat penyebab-penyebab dari suatu peristiwa atau memberi argumentargument yang menyokong suatu pernyataan, (5). Sintesis, menggabungkan, meramu, atau merangkai berbagai informasi menjadi satu kesimpulan atau menjadi suatu hal yang baru. Kemamuan berpikir induktif merupakan cirri kemampuan ini, (6). Evaluasi adalah jenjang berpikir paling tinggi dalam ranah kognitif dalam taksonomi bloom. Penilaian/Evaluasi merupakan kemampuan seseorang untuk membuat pertimbangan terhadap suatu kondisi, nilai atau ide, misalkan jika seseorang diharapkan dihadapkan pada beberapa pilihan maka ia akan mampu memilih satu pilihan terbaik sesuai dengan patokan patokan atau kriteria yang ada.

b. Ranah afektif

Ranah afektif berkaitan dengan aspek-aspek emosional, seperti perasaan, minat, sikap, perhatian, emosi, proses internalisasi diri dan pembentukan karateristik diri, terdiri dari: (1). Penerimaan, kepekaan seseorang dalam menerima dan kemudian memberikan perhatian terhadap rangsangan (stimulus) dari luar yang datang kepada dirinya, (2). Respon, memberi aksi terhadap stimulus yaitu seseorang sudah memiliki motivasi yang cukup sehingga ia bukan saja "mau memperhatikan", melainkan sudah memberikan respon, (3). Penilaian, pada tahap ini sudah mulai timbul proses internalisasi untuk memliki dan menghayati nilai dari stimulus yang dihadapi, (4). Pengorganisasian, pada tahap ini yang bersangkutan tidak hanya menginternalisasikan satu nilai tertentu seperti pada tahap komitmen, tetapi mulai melihat beberapa nilai yang relevan untuk disusun menjadi satu sistem nilai, (5). Karateristik, kemampuan untuk menghayati atau mempribadikan sistem nilai. Kalau pada tahap pengorganisasian diatas sistem nilai sudah dapat disusun, maka susunan itu belum konsisten didalam diri yang bersangkutan, artinya mudah berubah-ubah sesuai situasi yang dihadapi.

c. Ranah Psikomotor

Ranah psikomotor (keterampilan) berkaitan dengan aspek aspek keterampilan yang melibatkan fungsi sistem syaraf dan otot (neuronmuscular system) dan fungsi psikis yang terdiri dari: (1). Kesiapan, yaitu yang berhubungan dengan kesediaan untuk melatih diri tentang keterampilan tertentu yang dinyatakan dengan usaha untuk melaporkan kehadirannya, mempersiapkan alat, menyesuaikan diri dengan situasi, menjawab pertanyaan, (2). Meniru adalah kemampuan untuk melakukakn sesuai dengan contoh yang diamatinya walaupun belum mengerti hakikat atau makna dari keterampilan itu, seperti anak yang baru belajar bahasa meniru kata kata orang tanpa mengerti artinya, (3). Membiasakan yaitu seseorang dapat melakukan sesuatu keterampilan tanpa harus melihat contoh, sekalipun ia belum dapat mengubah polanya, (4). Adaptasi, yaitu seseorang sudah mampu melakukan modifikasi untuk disesuaikan dengan kebutuhan atau situasi tempat keterampilan itu dilaksanakan, (5). Menciptakan, dimana seseorang sudah mampu menciptakan sendri suatu karya..

Gagne (dalam Aunurrahman, 2009:47), menyimpulkan ada lima macam hasil belajar, yaitu: 1). Ketrampilan 
intelektual, 2). Strategi kognitif, 3). Informasi verbal, 4). Ketrampilan motorik, dan 5). Sikap. Tiap-tiap jenis hasil belajar yang dikemukakan memerlukan kondisikondisi tertentu yang perlu diatur dan dikontrol.

Suprijono (2009:5), hasil belajar adalah pola- pola perbuatan, nilai- nilai, pengertian- pengertian, sikap- sikap, apresiasi dan keterampilan. Menurut pemikiran Gagne (Agus 2010:5), hasil belajar berupa : (1). Informasi verbal yaitu kapabilitas mengungkapkan pengetahuan dalam bentuk bahasa, baik lisan maupun tertulis, (2). Keterampilan intelektual yaitu kemampuan mempersentasekan konsep dan lambing, (3). Strategi kognitif yaitu kecakapan menyalurkan dan mengarahkan aktivitas kognitifnya sendiri, (4). Kemampuan motorik yaitu kemampuan melakukan serangkaian gerak jasmani dalam urusan dan koordinasi, sehingga terwujud otomatisme gerak jasmani, (5). Sikap adalah kemampuan menerima atau menolak objek berdasarkan penilaian terhadap objek tersebut.

Hasil belajar dapat diketahui melalui penilaian dengan cara mengukur dan mengevaluasi tingkat keberhasilan belajar tersebut melalui tes. Penilaian hasil belajar ini bertujuan untuk mengetahui kemampuan belajar siswa dalam hal penguasaan materi. Untuk mengetahui hasil belajar siswa diadakan evaluasi. Evaluasi ini disebut sebagai hasil belajar, hasil belajar dapat diperoleh berupa pengetahuan, sikap dan ketrampilan.

Slameto (2010:54), belajar memiliki faktor-faktor yang mempengaruhinya yaitu:

a. Faktor Internal

Faktor Internal yaitu faktor-faktor yang terdapat dalam diri siswa. Dalam membahas faktor intern akan menjadi tiga faktor yaitu: (1). Faktor Jasmani, terdiri dari: a). Faktor Kesehatan, b). Cacat Tubuh, (2). Faktor Psikologis, terdiri dari: a). Inteligensi, b). Perhatian, c). Minat, d). Bakat, e). Motif, f). Kematangan, g). Kesiapan, (3). Faktor Kelelahan.

b. Faktor Eksternal

Faktor Eksternal yaitu faktor-faktor yang terdapat diluar dari diri siswa. Dapat dikelompokkan menjadi tiga faktor yaitu: (1). Faktor Keluarga, yang terdiri dari: a). Cara orang tua mendidik, b). Relasi antar anggota keluarga, c). Suasana rumah, d). Keadaan ekonomi keluarga, e). Pengertian orang tua, f). Latar belakang kebudayaan, (2). Faktor Sekolah yang meliputi: a). Metode Mengajar, b). Kurikulum, c). Relasi guru dengan siswa, d). Relasi siswa dengan siswa, e). Disiplin sekolah, f). Alat pengajaran, g). Waktu sekolah, h).Standar pelajaran diatas ukuran, i). Keadaan gedung, j). Metode belajar, k). Tugas rumah, (3). Faktor masyarakat, terdiri dari: a). Kegiatan siswa dalam masyarakat, b). Mass media, c). Teman bergaul, d). Bentuk kehidupan masyarakat.

c. Pendekatan belajar, yaitu upaya belajar siswa. Istarani (2012:1) mengatakan bahwa pendekatan memiliki kemiripan dengan strategi pembelajaran. Pendekatan dapat diartikan sebagai titik tolak atau sudut pandang kita terhadap proses pembelajaran. Istarani (2012:1) mengatakan pendekatan belajar meliputi teknik, strategi, metode dan model. Rostiyah N.K (dalam Istarani, 2012:1) mengatakan teknik adalah suatu pengetahuan tentang cara-cara mengajar yang dipergunakan oleh instruktur.

Istarani (2012:1) mengatakan bahwa strategi adalah suatu kegiatan pembelajaran yang harus dikerjakan guru dan siswa agar tujuan pembelajaran dapat dicapai secara efektif dan efisien. Wina sanjaya (2008:126) menambahkan strategi pembelajaran adalah suatu set materi dan prosedur pembelajaran yang digunakan bersama-sama untuk menimbulkan hasil belajar pada siswa.

Wina sanjaya (2008:126) metode adalah cara yang dapat digunakan untuk melaksanakan strategi. Dan pengertian model pembelajaran adalah seluruh rangkaian penyajian materi ajar yang meliputi segala aspek sebelum sedang dan sesudah pembelajaran dilakukan guru serta segala fasilitas yang terkait yang digunakan secara langsung atau tidak langsung dalam proses belajar mengajar (Istarani, 2012:1).

\subsection{Hasil Belajar DDK}

DDK (Dasar-dasar Kelistrikan) merupakan kompetensi baru di dalam Kurikulum 2013 untuk siswa kelas X. Dimana pelajaran ini merupakan Kompetensi dalam Program Keahlian Teknik Instalasi Tenaga Listrik.

Dalam Silabus Mata Pelajaran DDK meliputi beberapa sub kompetensi dasar yaitu: Mendeskripsikan arus listrik dan 
arus elektron, mendeskripsikan bahanbahan listrik, menggunakan elemen pasif dalam rangkaian listrik arus searah, menggunakan elemen pasif dalam rangkaian peralihan.

Dari penjelasan diatas maka yang dimaksud hasil belajar DDK dalam penelitian ini yaitu kemampuan dalam aspek kognitif yang dapat ditunjukkan melalui tes hasil belajar yang disusun sesuai materi pembelajaran yang diajarkan.

\subsection{Media Pembelajaran \\ 2.4.1. Pengertian Media Pembelajaran}

Kata media berasal dari bahasa latin medius yang secara harfiah berarti tengah, perantara, atau pengantar pesan dari sipengirim ke sipenerima pesan, merupakan bentuk jamak dari kata medium. Dalam kamus besar bahasa Indonesia (2008:892) mengatakan, media adalah alat (sarana) komunikasi seperti Koran, majalah, radio, televise, film, poster, dan spanduk. Arsyad (2006:3) bahwa Media adalah komponen sumber belajar atau wahana fisik yang mengandung materi instruksional dilingkungan siswa yang dapat merangsang siswa untuk belajar.

Banyak pakar dan juga organisasi yang memberikan batasan mengenai pengertian media. Beberapa diantaranya mengemukakan bahwa media adalah sebagai berikut :

1. Teknologi pembawa pesan yang dapat dimanfaatkan untuk keperluan pembelajaran. Jadi media adalah perluasan dari guru (Schram, 1982)

2. National Education Asociation (NEA) memberikan batasan bahwa media merupakan sarana komunikasi dalam bentuk cetak maupun audio visual termasuk teknologi perangkat kerasnya.

3. Briggs berpendapat bahwa media merupakan alat untuk memberikan perangsang bagi siswa supaya terjadi proses belajar.

4. Asociation of education communication Technology (AECT) memberikan batasan bahwa media merupakan segala bentuk dan saluran yang dipergunakan untuk proses penyaluran pesan

5. Segala sesuatu yang dapat digunakan untuk menyalurkan pesan yang dapat merangsang pikiran, perasaan, perhatian, dan kemauan siswa untuk belajar (Miarso, 1989).

6. Media adalah berbagai jenis komponen dalam lingkungan siswa yang dapat merangsangnya untuk belajar (Gagne, 1970).

7. Media adalah segala alat fisik yang dapat menyajikan pesan serta merangsang siswa untuk belajar Buku, film, kaset, film bingkai adalah contoh-contohnya (Briggs, 1970).

Rayandra Asyar (2011:8) bahwa media pembelajaran dapat dipahami sebagai segala sesuatu yang dapar menyampaikan atau menyalurkan pesan dari suatu sumber secara terencana, sehingga terjadi lingkungan belajar yang kondusif dimana penerimanya dapat melakukan proses belajar mengajar secara efisien dan efektif. Sehingga materi pembelajaran lebih cepat diterima siswa dengan utuh serta menarik minat siswa untuk belajar lebih lanjut.

Hamdani (2005) mengemukakan bahwa media pembelajaran adalah bahan, alat, atau teknik yang digunakan dalam kegiatan belajar mengajar dengan maksud agar proses interaksi komunikasi edukasi dengan guru dan siswa dapat berlangsung secara tepat guna dan berdaya guna. Musfiqon (2012:28) mendefinisikan media pembelajaran sebagai alat bantu berupa fisik maupun nonfisik yang sengaja digunakan sebagai alat perantara antara guru dan siswa dalam memahami materi pembelajaran agar lebih efektif dan efisien.

\subsubsection{Jenis-Jenis Media Pembelajaran}

Seels dan Glasgow (dalam Arsyad, 2007:33) mengelompokkan jenis media menjadi dua kategori luas berdasarkan perkembangannya, yaitu pilihan media tradisional dan pilihan media teknologi mutakhir. Pengelompokan berbagai jenis media juga dikemukankan oleh beberapa ahli. Leshin, Pollock dan Reigeluth (dalam Arsyad, 2007:36) mengklasifikasikan media ke dalam lima kelompok, yaitu (1) media berbasis manusia; (2) media berbasis cetak; (3) media berbasis visual; (4) media berbasis audio-visual; dan (5) media berbasis komputer. Sementara itu, Kemp dan Dayton (dalam Arsyad, 2007:27) mengelompokkan media ke dalam delapan jenis, yaitu (1) media cetakan, (2) media panjang, (3) overhead trasparancies, (4) rekaman audiotape, (5) seri slide dan filmstrips, (6) penyajian multi-image, (7) rekaman video dan film hidup, dan (8) komputer.

\subsubsection{Manfaat Media Pembelajaran}

Manfaat dari media menurut Kemp and Dayton, 1985 yaitu: (1). Penyampaian pesan pembelajaran dapat lebih terstandar, (2). Pembelajaran dapat lebih menarik, (3). Kualitas pembelajaran dapat ditingkatkan, (4). Waktu pelaksanaan pembelajaran dapat diperpendek, (5). Pembelajaran menjadi lebih interaktif dengan menerapkan teori belajar, (6). Proses pembelajaran dapat berlangsung kapanpun dan 
Pengaruh Penggunaan Media Pembelajaran Terhadap Hasil Belajar Dasar-Dasar Kelistrikan (DDK) Kelas X Program Keahlian Teknik Instalasi Tenaga Listrik (TITL) SMK Negeri 1 Lubuk Pakam

dimanapun diperlukan, (7). Peran guru berubah kearah yang positif, (8). Sikap positif siswa terhadap materi pembelajaran serta proses pembelajaran dapat ditingkatkan

Adapun manfaat media pembelajaran secara umum menurut Sanaky dalam Dani (2012:24) adalah: (a). Pengajaran lebih menarik perhatian pembelajar sehingga dapat menumbuhkan motivasi belajar. (b). Bahan pengajaran akan lebih jelas maknanya, sehingga dapat lebih dipahami pembelajar, serta memungkinkan pembelajar menguasai tujuan pengajaran yang baik, (c). Metode pengajaran bervariasi, tidak semata-mata hanya komunikasi verbal melalui penuturan kata-kata lisan pengajar, pembelajar tidak bosan, dan pengajar tidak kehabisan tenaga, (d). Pembelajar lebih banyak melakukan kegiatan belajar, sebab tidak hanya mendengar penjelasan dari pengajar saja, tetapi juga aktivitas yang dilakukan seperti: mengamati, melakukan, mendemonstrasikan, dan lain-lain.

\subsection{Media Crocodile}

Media Pembelajaran Crocodile Technology 609 adalah software untuk pembuatan rangkaian dan layout elektronika dalam 3D. Sebelumnya sudah pernah ada Crocodile clip, namun bedanya adalah yang terbaru ini menampilkan visual grafis seakan akan benda yang kita rangkai itu sudah dapat kita rasakan. Dan tidak hanya dirasakan tapi bisa kita simulasikan.

Kelebihan fitur Crocodile Technology 609 adalah:

1. Memiliki tampilan tools bar untuk mempermudah presentasi.

2. Memiliki komponen elektronika yang biasa kita pakai sehari hari.

3. Dapat merangkai layout, merancang PLC, dan memiliki keluaran suara.

4. Menampilkan Lampu LED persis seperti aslinya

5. Memudahkan kita dalam teknik pengontrolan motor.

6. Memiliki banyak layout yang bisa digunakan, terutama yang bersifat open source yang tersedia luas di internet.

Untuk menjalankan program crocodile dilakukan dengan langkah-langkah:

a. Untuk memulai menjalankan Crocodile Technology 609 paling sering dilakukan dari Start>All Program > Crocodile clips > Crocodile Technology 609. Maka akan muncul tampilan seperti ini
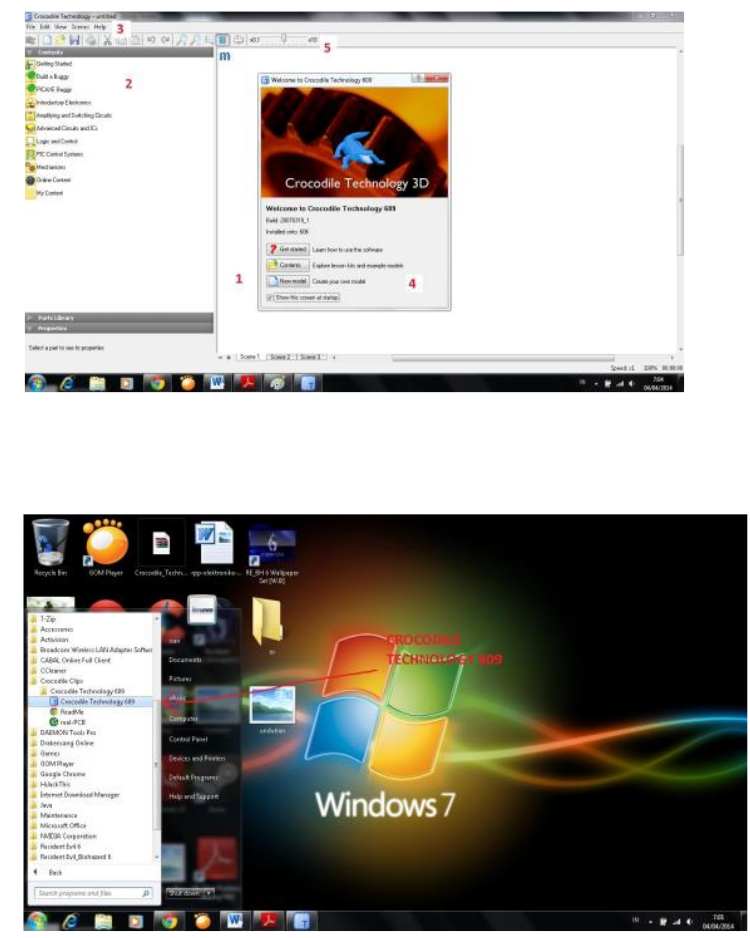

Gambar 2.1. Tampilan Awal

b. Maka setelah diklik akan muncul tampilan crocodile beserta bagiannya, seperti dibawah ini:

\section{Gambar 2.2. Lembar Kerja}

1. Lembar Kerja

2. Library (perpustakaan) komponen elektronika:

Tab Contents untuk konten konten yang sudah ada (contoh) yang diberikan oleh Crocodile clips.

Tab Properties untuk Menyetting atau Melihat dari komponen yang sudah kita letakkan ke dalam rangkaian

Tab Parts Library tempat dimana komponen elektronika yang kita butuhkan dalam merangkai

3. Tool bar, berisikan konten konten layaknya microsoft office, hanya saja ditambahkan scene dimana fungsi scene disitu merupakan lembar kerja yang berikutnya. 
Pengaruh Penggunaan Media Pembelajaran Terhadap Hasil Belajar Dasar-Dasar Kelistrikan (DDK) Kelas X Program Keahlian Teknik Instalasi Tenaga Listrik (TITL) SMK Negeri 1 Lubuk Pakam

4. Wizzard Startup, Pop up awal yang keluar untuk menanyakan apakah kita akan membuat baru sebuah lembar kerja (New Model) atau kita membuka Lembar kerja yang sudah kita simpan (contents)

5. Tampilan zoom, berfungsi untuk memperbesar dan memperkecil lembar kerja.

\subsubsection{Fungsi Toolbar}

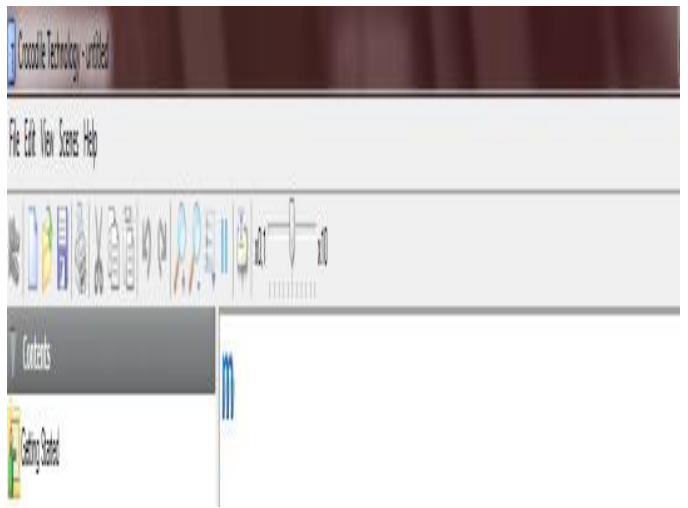

Gambar 2.3. Fungsi toobar

a) Delete parts adalah perintah untuk menghapus lembar kerja.

b) Create a new simulation adalah lembar kerja baru.

c) Open adalah perintah ini digunakan untuk membuka dokumen atau data dengan ekstensi.

d) Save adalah perintah ini digunakan untuk menyimpan dokumen yang berada di lembar kerja.

e) Print adalah perintah ini digunakan untuk mulai mencetak halaman skematik yang aktif atau sistem-sistem yang telah dipilih dalam project manager.

f) Cut adalah perintah ini digunakan untuk menghapus objek yang dipilh dari window dan menempatkannya di Clipboard. Perintah ini hanya aktif bila ada objek yang dipilih.

g) Copy adalah perintah ini digunakan untuk menduplikasikan objek yang dipilih dan mengirimnya ke Clipboard. Hanya aktif bila ada objek yang dipilih.

h) Paste adalah perintah ini digunakan untuk memindahkan objek yang disimpan di Clipboard ke window yang aktif. Perintah ini tidak berfungsi bila Clipboard dalam keadaan kosong.

i) Undo dan redo, undo adalah perintah ini digunakan untuk membatalkan efek perintah sebelumnya bila mungkin. Redo adalah perintah ini digunakan untuk membatalkan efek perintah Undo. j) Zoom Tool adalah perintah ini digunakan untuk mengubah tampilan menjadi besar dan kecil pada objek.

k) Space Property adalah pilihan untuk menjalankan program.

1) Run adalah perintah ini digunakan untuk menjalankan simulasi rangkaian yang telah jadi pada Clipboard.

m) Show/hide adalah untuk menampilkan dan menyembunyikan tampilan flowchart pada lembar kerja.

\subsubsection{Langkah Kerja}

Langkah - Langkah :

a. Masukkan PCB yang terdapat di TAB PART LIBRARY kedalam lembar kerja. Perhatikan gambar:

\section{Gambar 2.4. Tab Part Library}

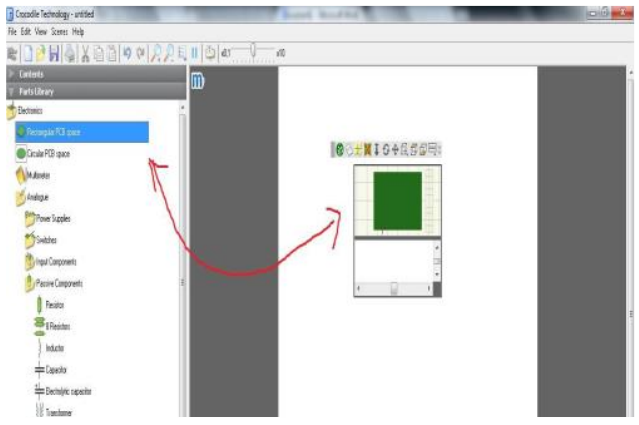

b. Masukkan Komponen:

1) LED ( yang berada di tab Light

Outputs)

2) Resistor ( berada di tab Passive components)

3) Baterai $9 v$ (berada di tab Power Supplies)

4) Switch SPST (berada di tab Switch) Ke

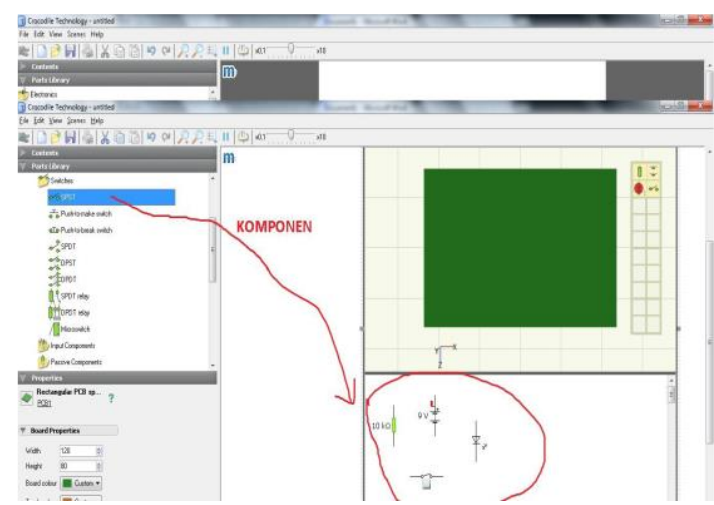

dalam kotak layout (dibawah kotak 3D)

Perhatikan Gambar :

Gambar 2.5. Pemindahan komponen ke Library 
Setelah itu kita rapikan, dan tarik garis wayar hingga terbentuklah sebuah LOOP, Kemudian Klik "create tracks and Place component with real PCB", ini berfungsi untuk membuat jalur layout sehingga nanti kita akan melihat bagaimanakah bentuk dari rangkaian kita. Lihat gambar :

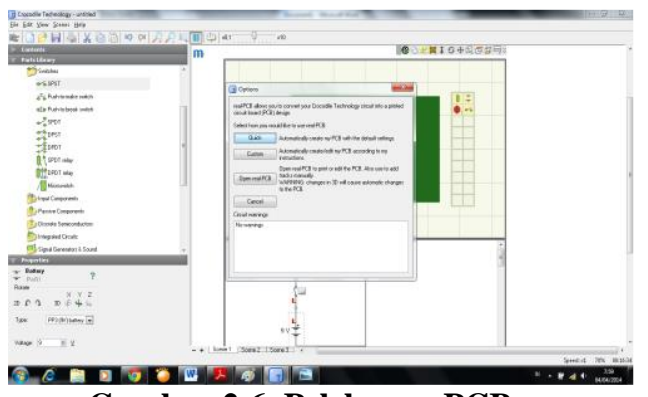

Gambar 2.6. Peleburan PCB

Pilih "quick", Biarkan Program bekerja hingga akan tampil 3D dari rangkaian yang kita buat tadi.

Gambar 2.7. Rangkaian yang telah jadi

\section{B. Penelitian Yang Relevan}

Penelitian yang relevan yang berkaitan dengan penggunaan media pembelajaran crocodile, yaitu:

1. Penelitian yang dilakukan oleh Eddi M. Sukisno (2013) di SMA Negeri Muhammadyah Malang tentang implementasi media crocodile physic yang berkesimpulan bahwa crocodile physic merupakan media simulasi, media ini memberikan gambaran simulasi. Pada materi listrik dinamis, siswa dapat melihat bagaimana simulasi rangkaian listrik digunakan. Pada pembelajaran dikelas eksperimen, siswa diberikan bagaimana rangkaian dibentuk, bagaimana alur rangkaian dibuat. Didapat hasil penelitian bahwa kelas eksperimen memiliki presentase ketuntasan $85 \% \quad$ lebih. Yaitu mendapatkan nilai diatas 80 dari nilai KKM.

2. Berdasarkan hasil penelitian Heri Purwadi, peneliti mengambil simpulan bahwa melalui penerapan model pembelajaran visual berbasis software crocodile physics dapat meningkatkan motivasi belajar siswa di kelas XI TPC SMK TKM Teknik Purworejo Tahun Pelajaran 2012/2013. Berdasarkan data hasil observasi, persentase motivasi belajar siswa meningkat dari rata-rata $45,55 \%$ pada pra siklus menjadi $54,455 \%$ pada siklus I dan meningkat lagi menjadi $73,61 \%$ pada siklus II.



Wakhid Akhdinirwanto (2010), Persentase motivasi belajar siswa pada tahap pra siklus rata-rata sebesar 56,66\%, meningkat menjadi $63,89 \%$ setelah diberi tindakan pada siklus I, dan meningkat lagi menjadi $76,29 \%$ setelah diberi tindakan pada siklus II. Untuk hasil angket motivasi tiap-tiap siswa dengan motivasi terendah meningkat dari $33,33 \%$ pada pra siklus menjadi $46,67 \%$ pada siklus I dan berubah cukup tinggi menjadi 73,33\% pada siklus II.

4. Hendro Kusworo, Ishafit, dan Winarti, 2008, Eksperimen Konstanta Planck Menggunakan Perangkat Lunak Physics Education Technology (PhET), bahwa hasil penelitian nya menyatakan kenaikan tingkat hasil belajar dari $45 \%$ menjadi $75 \%$.

5. Andri Youristiawan (2008)

Pembuatan Visualisasi Konsep Fluida untuk Peningkatan Mutu Pembelajaran Fisika pada Siswa Kelas XI MAN 1 Yogyakarta mengalami signifikan pada hasil belajar yaitu $54 \%$.

\section{Kerangka Berfikir}

Pengaruh Pengunaan Media

Pembelajaran Terhadap Hasil Belajar Dasar-Dasar Kelistrikan (DDK) Kelas X Program Keahlian Teknik Instalasi Tenaga Listrik (TITL) Di SMK Negeri 1 Lubuk Pakam.

Didalam penelitian ini eksperimen yang akan dilakukan yaitu melihat berpengaruh atau tidaknya media pembelajaran dengan melihat hasil belajar siswa. Penerapan Media Pembelajaran Crocodile dalam kegiatan belajar mengajar akan diterapkan untuk dapat meningkatkan hasil belajar Dasar-Dasar Kelistrikan. Dimana, yang digunakan untuk 
membedakan kedua perlakuan tersebut ditinjau dari hasil test yang akan diberikan setelah perlakuan selesai.

Dari kerangka teoritis telah diketahui bahwa Media Pembelajaran Crocodile adalah cara termudah untuk memberikan informasi dalam media bentuk gambar dan animasi.

Dari uraian diatas, Media Pembelajaran Crocodile yang dilakukan disekolah setempat, guru akan memandu siswa untuk belajar secara visual, lalu guru akan mengajarkan kepada siswa cara membuat sebuah rangkaian dengan menggunakan Media Crocodile. Setelah itu, siswa akan membuat rangkaian dengan Media Crocodile.

Dapat disimpulkan bahwa pengaruh Media Pembelajaran Crocodile pada materi Dasar-Dasar Kelistrikan lebih efektif dalam menjelaskan suatu rangkaian. Diduga bahwa dengan menerapkan Media Pembelajaran Crocodile pada kompetensi Dasar-Dasar Kelistrikan dalam kegiatan belajar mengajar akan meningkatkan hasil belajar siswa .

\section{Pengajuan Hipotesis}

Berdasarkan permasalahan dalam rumusan masalah dan untuk memudahkan penelitian dalam mengambil kesimpulan maka dapat diberikan jawaban sementara dari penelitian ini yaitu: Hasil belajar siswa pada kompetensi Dasar-Dasar Kelistrikan dengan menggunakan Media Pembelajaran Crocodile lebih tinggi dari pada hasil belajar pada Kompetensi Dasardasar Kelistrikan dengan menggunakan Media Gambar Papan Tulis kelas X Program Keahlian Teknik Instalasi Tenaga Listrik di SMK Negeri 1 Lubuk Pakam Tahun Ajaran 2013/2014.

\section{BAB III METODE PENELITIAN}

Penelitian ini dikategorikan dalam penelitian quasi eksperimen yaitu dengan membandingkan dua jenis media pembelajaran ditinjau dari hasil belajar siswa. Dua kelas dijadikan sampel, satu kelas diberi perlakuan dengan penerapan media pembelajaran crocodile dan satu kelas yang lain diberi penerapan pembelajaran dengan media gambar di papan tulis untuk mengetahui ada tidaknya perbedaan terhadap hasil belajar dasardasar kelistrikan.

\section{A. Lokasi, Tempat dan Waktu Penelitian \\ Lokasi penelitian ini dilaksanakan di} kelas X Program Keahlian Teknik Instalasi Tenaga Listrik SMK Negeri 1 Lubuk Pakam, pada semester genap tahun ajaran 2013/2014. Jenis penelitian yang dilaksanakan adalah penelitian quasi eksperimen.

\section{B. Populasi dan Sampel Penelitian}

1. Populasi Penelitian

Populasi adalah keseluruhan siswa yang dijadikan sebagai objek penelitian, yaitu seluruh siswa kelas $\mathrm{X}$ jurusan Teknik Instalasi Tenaga Listrik (TITL) SMK Negeri 1 Lubuk pakam T.A 2013/2014 sebanyak 2 kelas, yaitu $\mathrm{X}-\mathrm{L}_{1}$ dan $\mathrm{X}-\mathrm{L}_{2}$ jumlah 65 orang dengan rincian pada tabel 3.1 sebagai berikut :

\section{Tabel 3.1 Jumlah Siswa Kelas X Jurusan Teknik Instalasi Tenaga Listrik}

\begin{tabular}{|c|c|c|}
\hline Kelas & X-L 1 & X-L 2 \\
\hline Jumlah & 30 & 35 \\
\hline
\end{tabular}

\section{Sampel Penelitian}

Sampel dalam penelitian ini adalah seluruh dari populasi karena teknik pengambilan sample adalah teknik total sampling, yaitu seluruh anggota populasi dijadikan sample penelitian. Jumlah populasi 2 kelas sebanyak 65 orang siswa. Maka sample penelitian sama dengan populasi yaitu 2 kelas sebanyak 65 orang.

\section{Variabel Penelitian}

Adapun yang menjadi variabel penelitian ini adalah :

1. Variabel Bebas $\left(X_{1}\right.$ dan $\left.X_{2}\right)$ yaitu media pembelajaran Crocodile dan media gambar papan tulis.

2. Variabel Terikat (Y) yaitu Hasil Belajar Siswa pada Kompetensi DDK (Dasar-Dasar Kelistrikan).

\section{Defenisi Operasional}

Dalam penelitian ini terdapat dua variabel, maka variabel tersebut yaitu:

1. Media pembelajaran crocodile adalah media pembelajaran yang berbentuk simulasi yang dapat memberikan kemudahan kepada siswa dalam soal rangkaian listrik sehingga mendorong siswa untuk membuat hubungan antara pengetahuan yang dimilikinya 
Pengaruh Penggunaan Media Pembelajaran Terhadap Hasil Belajar Dasar-Dasar Kelistrikan (DDK) Kelas X Program Keahlian Teknik Instalasi Tenaga Listrik (TITL) SMK Negeri 1 Lubuk Pakam

dengan penerapannya dalam kehidupan. (Lodran, Luka., Matev, Poljan, yang sudah diterjemahkan)

2. Media gambar papan tulis adalah media pembelajaran yang menggunakan papan tulis sebagai perantara untuk menyampaikan materi dalam kegiatan belajar mengajar.

3. Hasil belajar DDK adalah gambaran tingkat penguasaan siswa kepada materi yang diajarkan dalam aspek kognitif yang dapat ditunjukkan melalui tes hasil belajar yang disusun sesuai materi pembelajaran yang diajarkan.

\section{E. Jenis dan Rancangan Penelitian}

Sampel yang diambil dalam penelitian ini dibagi atas dua kelas yaitu kelas Eksperimen dan kelas Kontrol. Untuk kelas Eksperimen diberikan media pembelajaran Crocodile, sedangkan untuk kelas Kontrol diberikan media gambar papan tulis. Jenis desain penelitian ini adalah desain yang menggunakan pretest dan postest, dengan tabel 3.2. sebagai berikut :

\section{Tabel 3.2. Desain Penelitian}

Dimana :

\begin{tabular}{|c|c|c|c|}
\hline Kelas & Pretest & Perlakuan & Postest \\
\hline Eksperimen & $\mathrm{P}_{1}$ & $\mathrm{X}_{1}$ & $\mathrm{P}_{2}$ \\
\hline Kontrol & $\mathrm{P}_{1}$ & $\mathrm{X}_{2}$ & $\mathrm{P}_{2}$ \\
\hline $\mathrm{P}_{1}=$ & Pretest \\
$\mathrm{P}_{2}=$ & Postest \\
$\mathrm{X}_{1}=$ & $\begin{array}{l}\text { Perlakuan } \\
\text { Eksperimen dengan media } \\
\text { pembelajaran Crocodile }\end{array}$ \\
$\mathrm{X}_{2}=$ & $\begin{array}{l}\text { Perlakuan pada kelas Kontrol } \\
\text { dengan media gambar dipapan } \\
\text { tulis. }\end{array}$ \\
Kedua kelas ini diberi tes awal \\
(pretest) dan diberi materi pembelajaran \\
yang sama. Perbedaan hanya terletak pada \\
perlakuan pembelajaran \\
menggunakan media crocodile dan \\
pembelajaran menggunakan media gambar \\
di papan tulis.
\end{tabular}

\section{F. Kontrol Terhadap Eksperimen.}

Kontrol terhadap eksperimen ada dua macam yakni kontrol secara eksternal dan internal. Kontrol secara internal atau validitas rancangan secara internal menunjukkan bahwa hasil penelitian ini adalah benar-benar hasil dari perlakuan yang diberikan (Arikunto, 2010). Hal-hal yang dikontrol dalam penelitian ini adalah

\section{Validitas internal.}

Validitas internal terdiri dari :

a. History

Untuk menghindari timbulnya efek lain dalam pelaksanaan penelitian ini akibat rentang waktu yang terlalu lama, maka pengaruh histori dikontrol dengan cara mengadakan post-test dengan jarak yang tidak begitu lama dengan waktu perlakuan.

b. Maturasi (kematangan)

Pengaruh akibat kematangan atau kejenuhan (maturasi) dikontrol dengan cara melaksanakan perlakuan pada jadwal jam pelajaran sesuai roster bidang studi Instalasi Listrik (IL) dengan waktu empat jam pelajaran untuk tiap kali mengadakan perlakuan/tiap pertemuan.

c. Kontaminasi sesama subjek penelitian

Dikontrol dengan cara mengawasi siswa ketika megerjakan tes yang diberikan, sehingga hasil tes, murni hasil kemampuan siswa yang bersangkutan.

d. Pengaruh perbedaan pemilihan subjek penelitian.

Dikontrol dengan cara mengambil subjek yang mempunyai kemampuan awal yang hampir sama, yakni kelas X L1 dan kelas X L2.

e. Mortalitas eksperimen

Pengaruh akibat kehilangan peserta eksperimen (mortality effect) dikontrol dengan tidak adanya peserta yang absen atau hilang sejak awal hingga pelaksaan eksperimen.

f. Interaksi antar faktor.

Interaksi antar faktor atau komunikasi antar kelas eksperimen dikontrol dengan cara tidak mengatakan apapun mengenai adanya penelitian kepada siswa, dan jadwal pertemuan yang berbeda harinya di antara kedua kelas tersebut.

\section{Validitas Eksternal}

a) Validitas populasi

Validitas ini merupakan pengontrolan terhadap populasi dan subjek penelitian, yakni sejauh mana populasi dari subjek penelitian tersebut dapat diharapkan memiliki akibat yang sama dengan apa 
Pengaruh Penggunaan Media Pembelajaran Terhadap Hasil Belajar Dasar-Dasar Kelistrikan (DDK) Kelas X Program Keahlian Teknik Instalasi Tenaga Listrik (TITL) SMK Negeri 1 Lubuk Pakam

yang dialami oleh subjek sampel penelitian.

Kesahihan ini dikontrol dengan cara :

1) Mengambil sampel sesuai dengan karakteristik populasi penelitian yaitu dengan mengambil sampel seluruh siswa kelas X SMK Negeri 1 Lubuk Pakam.

2) Masing-masing kelas yaitu kelas eksperimen1 dan kelas eksperimen2 diberi perlakuan yang berbeda, yakni satu kelas diberi perlakuan dengan media crocodile dan satu kelas lagi diberi perlakuan dengan media gambar di papan tulis.

b) Validitas Ekologi

Validitas ini dikontrol dengan cara :

1) Tidak memberitahukan kepada siswa bahwa mereka sedang menjadi objek penelitian

2) Membuat suasana kelas sama dengan keadaan sehari-hari yaitu dengan tidak mengubah jadwal pembelajaran, dan memberi perlakuan yang sama bagi semua siswa di dalam kelas.

3) Memberi perlakuan dalam situasi dan kondisi yang sesuai dengan keadaan sehari-hari, untuk menghindari timbulnya efek "Hawthtrone" (subjek menjadi cenderung untuk percaya terhadap efektifitas perlakuan, hanya karena suasana diatur sedemikian rupa sehingga menimbulkan kesan sangat ilmiah dan profesional pada diri siswa.

Tabel 3.3. Kerangka Perlakuan.

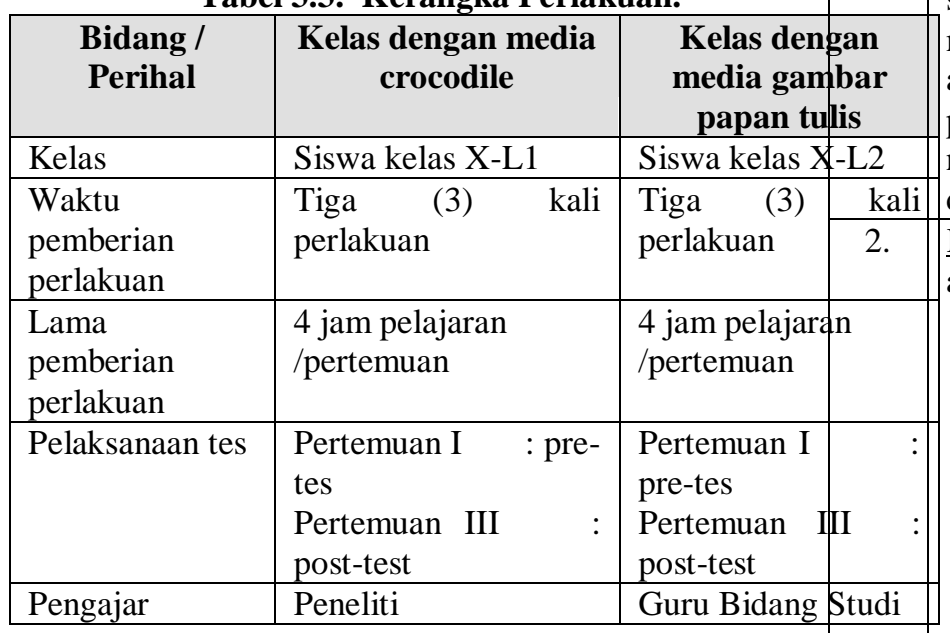

G. Prosedur Pelaksanaan Penelitian Adapun prosedur pelaksanaan dalam penelitian ini adalah sebagai berikut:
1. Mengadakan pretest (tes awal) pada kedua kelas untuk mengetahui kemampuan awal siswa.

2. Mengadakan perlakuan pada kelompok Eksperimen (X LISTRIK 1) yang diajar dengan menggunakan media pembelajaran Crocodile

3. Mengadakan perlakuan pada kelompok Kontrol (X LISTRIK 2) yang diajar dengan media gambar papan tulis.

4. Mengadakan postest (tes akhir) pada kedua kelas untuk menjaring data penelitian.

Sedangkan kerangka perlakuan (skenario) Media pembelajaran crocodile yang akan diberikan pada kelas eksperimen adalah pada tabel 3.4. berikut:

Tabel 3.4. Skenario Pembelajaran Media Crocodile

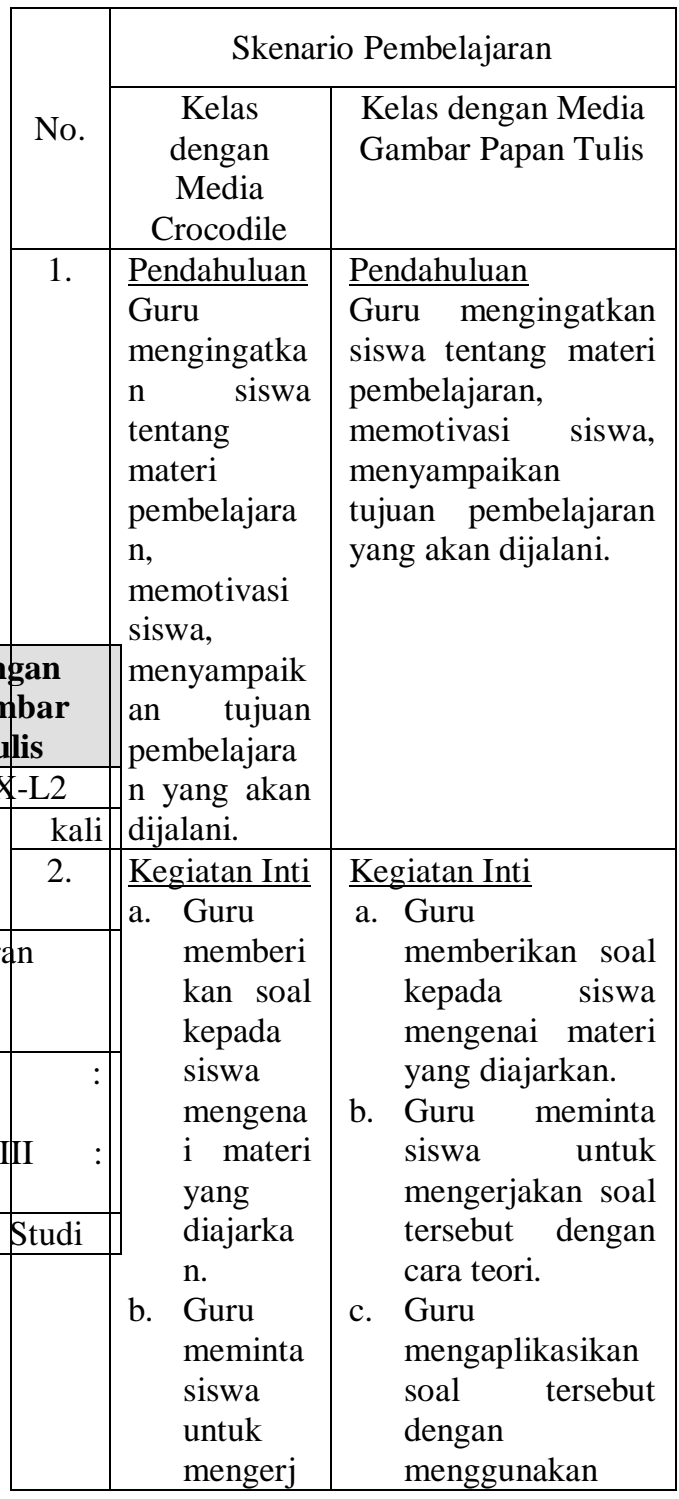


Pengaruh Penggunaan Media Pembelajaran Terhadap Hasil Belajar Dasar-Dasar Kelistrikan (DDK) Kelas X Program Keahlian Teknik Instalasi Tenaga Listrik (TITL) SMK Negeri 1 Lubuk Pakam

\begin{tabular}{|c|c|c|}
\hline & $\begin{array}{l}\text { akan } \\
\text { soal } \\
\text { tersebut } \\
\text { dengan } \\
\text { cara } \\
\text { teori. } \\
\text { c. } \\
\text { Guru } \\
\text { mengapl } \\
\text { ikasikan } \\
\text { soal } \\
\text { tersebut } \\
\text { dengan } \\
\text { menggu } \\
\text { nakan } \\
\text { media } \\
\text { crocodil } \\
\text { e. } \\
\text { Guru } \\
\text { mengim } \\
\text { plikasi } \\
\text { soal } \\
\text { yang } \\
\text { diberika } \\
\text { n pada } \\
\text { layar } \\
\text { tampilan } \\
\text { media } \\
\text { crocodil } \\
\text { e. } \\
\text { e. Guru } \\
\text { meminta } \\
\text { salah } \\
\text { satu } \\
\text { siswa } \\
\text { untuk } \\
\text { mengula } \\
\text { ng soal } \\
\text { tersebut } \\
\text { dengan } \\
\text { menggu } \\
\text { nakan } \\
\text { media } \\
\text { crocodil } \\
\text { e } \\
\end{array}$ & $\begin{array}{ll} & \text { media gambar } \\
\text { papan tulis. } \\
\text { d. Guru meminta } \\
\text { salah satu siswa } \\
\text { untuk mengulang } \\
\text { soal tersebut } \\
\text { dengan } \\
\text { menggunakan } \\
\text { media gambar } \\
\text { papan tulis }\end{array}$ \\
\hline 3. & $\begin{array}{l}\text { Penutup } \\
\text { Pada akhir } \\
\text { pembelajara } \\
\mathrm{n} \text { guru } \\
\text { bersama } \\
\text { siswa } \\
\text { menyimpulk } \\
\text { an hasil } \\
\text { pembelajara } \\
\text { n yang telah } \\
\text { dilakukan } \\
\text { dan } \\
\text { memberikan } \\
\text { soal-soal }\end{array}$ & $\begin{array}{lr}\text { Penutup } & \\
\text { Pada } & \text { akhir } \\
\text { pembelajaran } & \text { guru } \\
\text { bersama } & \text { siswa } \\
\text { menyimpulkan } & \text { hasil } \\
\text { pembelajaran yang } & \text { yan dilakukan dan } \\
\text { telah } & \text { memberikan soal-soal } \\
\text { untuk dikerjakan } \\
\text { dirumah dengan } \\
\text { menggunakan teori. }\end{array}$ \\
\hline
\end{tabular}

\begin{tabular}{|l|l|}
\hline untuk \\
dikerjakan \\
dirumah \\
dengan \\
menggunaka \\
$\mathrm{n}$ teori \\
kemudian \\
mengaplikas \\
ikannya \\
dengan \\
media \\
crocodile.
\end{tabular}

\section{H. Instrumen Penelitian}

Instrumen penelitian yang digunakan untuk mengumpulkan data hasil belajar siswa adalah tes hasil belajar siswa pada materi pokok Dasar-dasar Kelistrikan. Tes ini berbentuk pilihan berganda sebanyak 35 soal dengan empat option pilihan. Dalam penyusunan tes ini digunakan dari kumpulan soal-soal dari materi pelajaran. Kriteria penilaian adalah memberikan skor 1 untuk setiap soal yang dijawab benar dan skor 0 untuk setiap soal yang dijawab salah. Untuk penskoran instrumen dilakukan dengan cara tanpa hukuman yaitu menjumlahkan seluruh pertanyaan yang dijawab benar dan seluruh soal yang dijawab salah atau apabila banyaknya angka dihitung dari banyaknya jawaban yang cocok dengan kunci jawaban (Arikunto, 2011:226). Adapun kisi-kisi tes mata pelajaran DDK adalah ditunjukkan pada tabel 3.5. Kisi-kisi Tes Hasil Belajar DDK.

Tabel 3.5.

Kisi-Kisi Instrumen Tes Hasil Belajar

\begin{tabular}{|c|c|c|c|c|c|c|}
\hline \multirow[b]{2}{*}{ No. } & \multirow[t]{2}{*}{ Indikator } & \multicolumn{4}{|c|}{ Aspek Kognitif } & \multirow[b]{2}{*}{ Jlh } \\
\hline & & $\mathrm{C}_{1}$ & $\mathbf{C}_{2}$ & $\mathbf{C}_{3}$ & $\mathrm{C}_{4}$ & \\
\hline 1. & $\begin{array}{l}\text { Mendeskrips } \\
\text { kan arus } \\
\text { istrik dan } \\
\text { rus elektron }\end{array}$ & $\begin{array}{l}1, \\
2, \\
3 \\
4 \\
20\end{array}$ & 5,6 & & $\begin{array}{l}32, \\
33, \\
34, \\
35 .\end{array}$ & 11 \\
\hline 2. & $\begin{array}{l}\text { Mendeskrips } \\
\text { kan elemen } \\
\text { asif dalam } \\
\text { angkaian } \\
\text { istrik arus }\end{array}$ & $\begin{array}{l}7 \\
8 \\
9\end{array}$ & 7,21 & & 16 & 13 \\
\hline 3. & $\begin{array}{l}\text { earah } \\
\text { Menggunaka }\end{array}$ & $\begin{array}{l}11, \\
12, \\
13\end{array}$ & & 25,29 & $\begin{array}{l}22, \\
23 \\
24,\end{array}$ & 11 \\
\hline
\end{tabular}


Pengaruh Penggunaan Media Pembelajaran Terhadap Hasil Belajar Dasar-Dasar Kelistrikan (DDK) Kelas X Program Keahlian Teknik Instalasi Tenaga Listrik (TITL) SMK Negeri 1 Lubuk Pakam

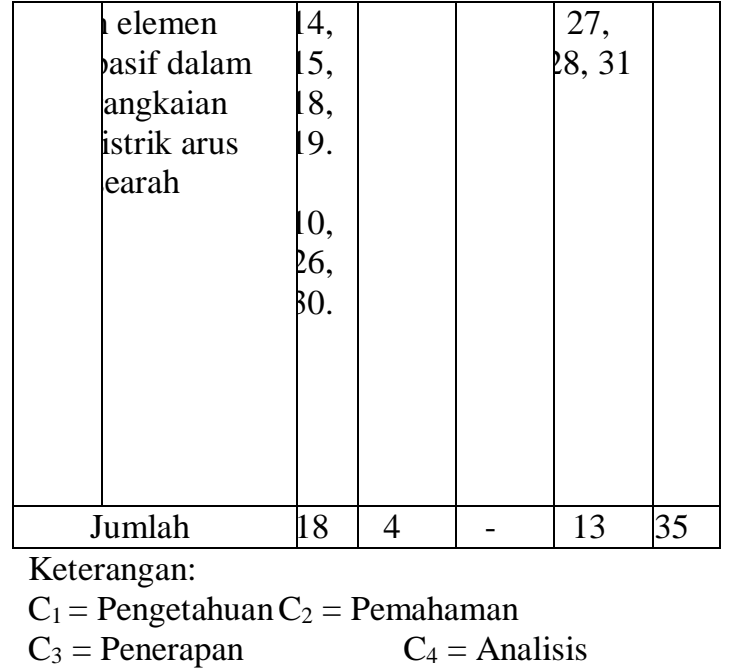

\section{Uji Coba Instrumen}

Setelah tes hasil belajar disusun, sebelum digunakan untuk menjaring data penelitian terlebih dahulu diuji cobakan untuk melihat kesahihan dan keterandalan butir tes dengan cara yaitu uji coba instrumen. Uji coba ini juga bertujuan untuk mendapatkan alat ukur yang benarbenar dapat menjaring data yang akurat agar kesimpulan yang diambil sesuai dengan kenyataan Sebelum pengumpulan data dilakukan terlebih dahulu dilakukan uji coba instrumen penelitian yang dilaksanakan pada kelas $\mathrm{X}$ program keahlian Teknik Instalasi Tenaga Listrik SMK Negeri 1 Lubuk Pakam.

\section{Validitas Tes}

Untuk menguji validitas tes digunakan rumus korelasi product moment dari Karl Person (Arikunto, 2011:79) sebagai berikut:

$$
r_{p h i}=\frac{M_{P}-M_{t}}{S_{t}} \sqrt{\frac{p}{q}}
$$

Keterangan:

$$
r_{p h i}=\text { Koefisien korelasi biserial }
$$

$\mathrm{M}_{\mathrm{p}}=$ Rerata skor dari subjek yang menjawab betul

$\mathrm{M}_{\mathrm{t}}=$ Rerata skor total

$\mathrm{S}_{\mathrm{t}}=$ Standar deviasi dari skor total

$\mathrm{p}=$ Proporsi siswa yang menjawab benar $\left(p=\frac{\text { banyaknyasiswayangbenar }}{\text { jumlahseluruhsiswa }}\right)$

$\mathrm{q}=$ Proporsi siswa yang menjawab salah (Arikunto 2011:79)

$$
(q=1-p)
$$

Selanjutnya harga $\quad r_{\text {hitung }}$ dikonsultasikan dengan harga $r_{\text {tabel }}$ pada taraf signifikan 5\%. Apabila $r_{\text {hitung }}>r_{\text {tabel }}$ maka butir tes tersebut valid.

Dari hasil Uji coba Instrumen, didapat perhitungan validitas Tes Kognitif Dasar-dasar Kelistrikan yaitu pada tabel 3.6 dibawah ini:

\begin{tabular}{|c|c|c|c|}
\hline No & $\mathrm{r}_{\text {hitung }}$ & $\mathrm{r}_{\text {tabel }}$ & Status \\
\hline 1 & 0,52 & 0,349 & $\mathrm{~V}$ \\
\hline 2 & 0,46 & 0,349 & $\mathrm{~V}$ \\
\hline 3 & 0,39 & 0,349 & $\mathrm{~V}$ \\
\hline 4 & 0,43 & 0,349 & $\mathrm{~V}$ \\
\hline 5 & $-0,38$ & 0,349 & $\mathrm{TV}$ \\
\hline 6 & 0,48 & 0,349 & $\mathrm{~V}$ \\
\hline 7 & 0,52 & 0,349 & $\mathrm{~V}$ \\
\hline 8 & 0,36 & 0,349 & $\mathrm{~V}$ \\
\hline 9 & 0,47 & 0,349 & $\mathrm{~V}$ \\
\hline 10 & 0,56 & 0,349 & $\mathrm{~V}$ \\
\hline 11 & 0,46 & 0,349 & $\mathrm{~V}$ \\
\hline 12 & 0,46 & 0,349 & $\mathrm{~V}$ \\
\hline 13 & 0,56 & 0,349 & $\mathrm{~V}$ \\
\hline 14 & 0,38 & 0,349 & $\mathrm{~V}$ \\
\hline 15 & 0,72 & 0,349 & $\mathrm{~V}$ \\
\hline 16 & 0,69 & 0,349 & $\mathrm{~V}$ \\
\hline 17 & 0,41 & 0,349 & $\mathrm{~V}$ \\
\hline 18 & $-0,16$ & 0,349 & TV \\
\hline 19 & $-0,3$ & 0,349 & $\mathrm{TV}$ \\
\hline 20 & 0,48 & 0,349 & $\mathrm{~V}$ \\
\hline 21 & 0,53 & 0,349 & $\mathrm{~V}$ \\
\hline 22 & 0,41 & 0,349 & $\mathrm{~V}$ \\
\hline 23 & 0,72 & 0,349 & $\mathrm{~V}$ \\
\hline 24 & 0,35 & 0,349 & $\mathrm{~V}$ \\
\hline 25 & 0,45 & 0,349 & $\mathrm{~V}$ \\
\hline 26 & 0,45 & 0,349 & $\mathrm{~V}$ \\
\hline 27 & $-0,02$ & 0,349 & TV \\
\hline 28 & $-0,02$ & 0,349 & TV \\
\hline 29 & 0,55 & 0,349 & $\mathrm{~V}$ \\
\hline 30 & 0,43 & 0,349 & $\mathrm{~V}$ \\
\hline 31 & 0,43 & 0,349 & $\mathrm{~V}$ \\
\hline 32 & 0,5 & 0,349 & $\mathrm{~V}$ \\
\hline 33 & 0,56 & 0,349 & $\mathrm{~V}$ \\
\hline
\end{tabular}

Tabel 3.6.Hasil Perhitungan Validitas Tes Kognitif Dasar-Dasar Kelistrikan. 
Pengaruh Penggunaan Media Pembelajaran Terhadap Hasil Belajar Dasar-Dasar Kelistrikan (DDK) Kelas X Program Keahlian Teknik Instalasi Tenaga Listrik (TITL) SMK Negeri 1 Lubuk Pakam

\begin{tabular}{|l|l|l|l|}
34 & 0,42 & 0,349 & $\mathrm{~V}$ \\
\hline 35 & 0,51 & 0,349 & $\mathrm{~V}$ \\
\hline
\end{tabular}

\section{Reliabilitas Tes}

Untuk menentukan reliabilitas tes dilakukan dengan menggunakan rumus KR-20 seperti yang dikemukakan oleh Arikunto (2011:100) yaitu :

$$
r_{11}=\left[\frac{n}{n-1}\right] \cdot\left[\frac{S t^{2}-\Sigma_{p q}}{S t^{2}}\right]
$$

Keterangan :

$\mathrm{R}_{11}=$ Koefisien Reliabilitas Instrumen Tes

$\mathrm{p}$ = Banyak siswa yang menjawab soal dengan benar

$\mathrm{q}$ = Banyak siswa yang menjawab soal dengan salah

$\mathrm{n}$ = banyak butir pertanyaan

St $=$ Standar deviasi dari tes

Reliabilitas tes yang diperoleh dari hasil perhitungan dikonsultasikan dengan indeks korelasi yang diberikan Arikunto (2011:100), yaitu

0,800-1,000 : Sangat Tinggi

0,600-0,799 : Tinggi

0,400-0,500 : Cukup

0,200-0,399 : Rendah

$>0,200 \quad$ : Sangat Rendah

Dan didapat harga reliabilitas tes ssebesar 0,79. Sesuai dengan hasil perhitungan yang dikonsultasikan dengan indeks korelasi, reliabilitas tes ini termasuk dalam kategori tinggi.

\section{Analisis Butir}

Arikunto (2011:206) mengatakan bahwa analisis butir soal dilakukan bertujuan untuk mengadakn identifikasi soal-soal yang baik, kurang baik dan soal yang jelek.

\subsection{Taraf Kesukaran Item}

Indeks kesukaran soal ditentukan dengan menggunakan rumus :

$$
P=\frac{B}{J S}
$$

(Arikunto,

2011:208)

Keterangan :

$\mathrm{P}=$ Indeks kesukaran soal

$\mathrm{B}$ = Banyaknya subjek yang menjawab benar

$\mathrm{JS}=$ Jumlah siswa
Dengan kriteria taraf kesukaran soal adalah sebagai berikut (Arikunto, 2011 :210).

$1,00-0,30=$ Sukar

$0,30-0,70=$ Sedang

$0,71-1,00=$ Mudah

Dari perhitungan taraf kesukaran item diperoleh jumlah soal dimana taraf kesukarannya mudah 9 soal, sedang berjumlah 23 soal dan sukar berjumlah 3 soal.

\subsection{Daya Pembeda Soal}

Daya pembeda butir soal adalah kemampuan butir dalam membedakan responden mana yang memiliki kemampuan tinggi dan mana yang memiliki kemampuan rendah. Daya pembeda dihitung dengan rumus (Arikunto, $2011: 213)$ :

$$
\boldsymbol{D}=\frac{\boldsymbol{B}_{A}}{\boldsymbol{J}_{A}}-\frac{\boldsymbol{B}_{B}}{\boldsymbol{B}_{A}}
$$

Keterangan :

D = Daya beda

$\mathrm{B}_{\mathrm{A}}=$ Banyaknya responden kelompok atas menjawab benar

$\mathrm{B}_{\mathrm{B}}=$ Banyaknya responden kelompok bawah menjawab benar

$\mathrm{J}_{\mathrm{A}} \quad=$ Jumlah responden kelompok atas

$\mathrm{J}_{\mathrm{B}} \quad=$ Jumlah responden kelompok bawah

$$
\text { Harga daya pembeda }
$$

dikonfirmasikan dengan kriteria sebagai berikut (Arikunto, 2011:218) :

$$
\begin{aligned}
& 0,00-0,20=\text { Buruk } \\
& 0,20-0,40=\text { Cukup } \\
& 0,40-0,70=\text { Baik } \\
& 0,70-1,00=\text { Baik Sekali }
\end{aligned}
$$

\subsection{Uji Distraktor (Pengecoh)}

Pengecoh (Distractor) merupakan salah satu komponen dalam instrumen tes yang berfungsi mengecoh tes dalam menentukan jawaban. Dengan kata lain pengecoh ini dapat dikatakan sebagai jawaban yang hampir menyerupai jawaban sebenarnya dalam tiap butir instrumen, sehingga tes akan bingung untuk memilih jawaban. Pengecoh ini biasanya digunakan dalam instrumen tes berbentuk pilihan berganda.

Pengecoh yang tidak dipilih sama sekali oleh tes, berarti pengecoh tersebut belum berfungsi dengan baik untuk mengecoh tes. Sebaliknya, sebuah distractor telah berfungsi dengan baik apabila pengecoh tersebut dapat mengecoh tes dalam menentukan pilihan jawaban, sehingga setiap alternatif jawaban yang 
Pengaruh Penggunaan Media Pembelajaran Terhadap Hasil Belajar Dasar-Dasar Kelistrikan (DDK) Kelas X Program Keahlian Teknik Instalasi Tenaga Listrik (TITL) SMK Negeri 1 Lubuk Pakam

disediakan mempunyai daya tarik besar bagi tes yang kurang menguasai materi tes yang akan diberikan.

Penilaian kriteria mengenai pengecoh (distractor) dibedakan dalam tiga tahapan, yaitu :

a) Baik untuk digunakan.

b) Perlu direvisi sebelum digunakan (kurang baik).

c) Tidak layak digunakan (buruk).

Dari hasil perhitungan distraktor, didapat kualitas pengecoh sesuai pada tabel dibawah ini:

Tabel 3.9. Kualitas Pengecoh

\begin{tabular}{|c|c|c|c|c|}
\hline \multirow{2}{*}{ No. } & \multicolumn{4}{|c|}{ Kualitas Pengecoh } \\
\hline & $\mathbf{A}$ & $\mathbf{B}$ & $\mathbf{C}$ & D \\
\hline 1 & bu & $\mathrm{kb}$ & bu & $\mathrm{bu}$ \\
\hline 2 & $\mathrm{~kb}$ & bu & bu & $\mathrm{bu}$ \\
\hline 3 & sbu & $\mathrm{kb}$ & bu & bu \\
\hline 4 & bu & bu & $\mathrm{kb}$ & bu \\
\hline 5 & bu & bu & bu & $\mathrm{bu}$ \\
\hline 6 & bu & $\mathrm{kb}$ & bu & bu \\
\hline 7 & $\mathrm{bu}$ & bu & bu & $\mathrm{kb}$ \\
\hline 8 & bu & $\mathrm{bu}$ & $\mathrm{bu}$ & $\mathrm{b}$ \\
\hline 9 & $\mathrm{~kb}$ & bu & $\mathrm{kb}$ & $\mathrm{bu}$ \\
\hline 10 & bu & bu & B & $\mathrm{bu}$ \\
\hline 11 & $\mathrm{~b}$ & bu & bu & $\mathrm{bu}$ \\
\hline 12 & sba & bu & bu & $\mathrm{bu}$ \\
\hline 13 & bu & bu & $\mathrm{bu}$ & $\mathrm{b}$ \\
\hline 14 & bu & $\mathrm{Bu}$ & $\mathrm{bu}$ & sba \\
\hline 15 & $\mathrm{bu}$ & $\mathrm{Kb}$ & bu & $\mathrm{Kb}$ \\
\hline 16 & bu & sba & $\mathrm{kb}$ & $\mathrm{Bu}$ \\
\hline 17 & bu & $\mathrm{kb}$ & $\mathrm{bu}$ & $\mathrm{Bu}$ \\
\hline 18 & bu & b & bu & $\mathrm{Bu}$ \\
\hline 19 & $\mathrm{~kb}$ & $\mathrm{bu}$ & sba & $\mathrm{Bu}$ \\
\hline 20 & bu & $\mathrm{kb}$ & $\mathrm{kb}$ & $\mathrm{Bu}$ \\
\hline 21 & $\mathrm{bu}$ & sbu & $\mathrm{bu}$ & $\mathrm{kb}$ \\
\hline 22 & sbu & $\mathrm{bu}$ & $\mathrm{kb}$ & $\mathrm{bu}$ \\
\hline 23 & $\mathrm{bu}$ & $\mathrm{kb}$ & B & $\mathrm{bu}$ \\
\hline 24 & sbu & $\mathrm{bu}$ & $\mathrm{kb}$ & $\mathrm{bu}$ \\
\hline 25 & $\mathrm{~kb}$ & $\mathrm{bu}$ & B & $\mathrm{bu}$ \\
\hline 26 & $\mathrm{~b}$ & $\mathrm{bu}$ & bu & $\mathrm{kb}$ \\
\hline 27 & b & $\mathrm{bu}$ & $\mathrm{kb}$ & $\mathrm{bu}$ \\
\hline 28 & $\mathrm{~kb}$ & $\mathrm{bu}$ & sbu & $\mathrm{bu}$ \\
\hline 29 & sbu & $\mathrm{kb}$ & $\mathrm{bu}$ & $\mathrm{bu}$ \\
\hline 30 & $\mathrm{~kb}$ & bu & $\mathrm{bu}$ & bu \\
\hline
\end{tabular}

\begin{tabular}{|c|c|c|c|c|}
\hline 31 & $\mathrm{~kb}$ & $\mathrm{bu}$ & $\mathrm{sba}$ & $\mathrm{bu}$ \\
\hline 32 & $\mathrm{sba}$ & $\mathrm{bu}$ & $\mathrm{bu}$ & $\mathrm{kb}$ \\
\hline 33 & $\mathrm{~kb}$ & $\mathrm{bu}$ & $\mathrm{kb}$ & $\mathrm{bu}$ \\
\hline 34 & $\mathrm{bu}$ & $\mathrm{kb}$ & $\mathrm{bu}$ & $\mathrm{bu}$ \\
\hline 35 & $\mathrm{bu}$ & $\mathrm{kb}$ & $\mathrm{kb}$ & $\mathrm{bu}$ \\
\hline
\end{tabular}

\section{J. Teknik Analisis Data}

Untuk analisa data yang diperoleh dari penelitian ini digunakan perangkat tes parametrik karena asumsi yang melandasi penggunaannya terpenuhi sehingga perangkat tes tersebut sangat kuat untuk menguji hipotesis nol. Salah satu asumsi yang melandasi pemakaian teknik statistik ini adalah adanya normalitas dan homogenitas data. Oleh karena itu, uji normalitas dan uji homogenitas dilakukan.

Agar tes statistik yang digunakan untuk menganalisis data eksperimen ini dapat dipertanggung jawabkan, maka perlu dilakukan :

\section{Deskripsi Data}

Untuk mendeskripsikan data hasil belajar Dasar-Dasar Kelistrikan berdasarkan kelompok perlakuan, maka data tersebut dianalisis dengan menggunakan statistif deskriptif yaitu dengan cara menghitung rata-rata skor atau mean (M), simpangan baku atau standard deviasi (s), dan Varians $\left(\sigma^{2}\right)$.

1. Mean Skor $(M)$ dihitung dengan rumus (dalam Hutasoit. 2005)

$$
M=\sum_{n}^{X}
$$

2. Standard deviasi $(s)$ dihitung dengan menggunakan rumus (Sudjana, dalam Hutasoit.,2005).

$$
s=\sqrt{\frac{n \sum X^{2}-\left(\sum X\right)^{2}}{n(n-1)}}
$$

Dimana:

$$
\begin{aligned}
\mathrm{n} & =\text { Jumlah sampel penelitian } \\
\sum \mathrm{X} & =\text { Jumlah produk skor } \\
\sum \mathrm{Y} & =\text { Jumlah kuadrat produk skor }
\end{aligned}
$$

3. Tingkat Kecendrungan, dihitung berdasarkan hasil dari Mean (Mi) dan Standar Deviasi (Ali Sya'ban., M.Pd, 2005) yaitu:

Tingkat kategori ini didasarkan atas acuan kurva normal dengan perhitungan menggunakan mean ideal (Mi) dan standard deviasi ideal (SDi), yaitu: 
Untuk $\mathrm{Mi}=0,5 \times($ skor tertinggi + skor terkecil)

$\mathrm{SDi}=1 / 6 \times($ skor tertinggi - skor terkecil)

Maka jika dimasukan dalam kategorisasi data adalah sebagai berikut:

$\mathrm{Mi}+1,5 \mathrm{SDi}<\mathrm{X}=$ Sangat Baik

$\mathrm{Mi} \leq \mathrm{X}<\mathrm{Mi}+1,5 \mathrm{SDi}=$ Baik

$\mathrm{Mi}-1,5 \mathrm{SDi} \leq \mathrm{X}<\mathrm{Mi}=$ Cukup Baik

$\mathrm{X}<\mathrm{Mi}-1,5 \mathrm{SDi}=$ Kurang Baik

\section{Uji Persyaratan Analisis}

Sebelum dilakukan uji hipotesis penelitian, data hasil belajar Dasar-dasar Kelistrikan berdasarkan kelompok perlakuan harus memenuhi persyaratan :

\section{a. Uji Normalitas}

Pada penelitian ini uji normalitas digunakan untuk mengetahui distribusi data hasil belajar Dasar-Dasar Kelistrikan dari kedua perlakuan, apakah data tersebut berdistribusi normal atau tidak. Uji Normalitas data digunakan uji Lilifors sebagai berikut:

1) Data $X_{1}, X_{2}, \ldots X_{n}$ dijadikan bilangan baku $\mathrm{Zi}$ yaitu dengan rumus:

$$
Z_{i}=\frac{X_{i}-\bar{X}}{S}
$$

2) Menghitung Peluang $F(z i)=P(Z<Z i)$

3) Selanjutnya menghitung Proporsi $\mathrm{S}$ (zi) dengan rumus:

$$
S\left(Z_{i}\right)=\frac{F k u m}{\Sigma F i}(\text { Sudjana, 2010) }
$$

4) Menghitung selisih $\mathrm{F}(\mathrm{zi})-\mathrm{S}(\mathrm{zi})$ kemudian menentukan harga mutlak.

5) Mengambil harga Lo yaitu harga yang paling besar dari harga mutlak untuk menerima dan menolak hipotesis dibandingkan Lo dengan nilai kritis L yang diambil dari daftar nilai krisis uji lilifors dengan taraf signifikan 5\%.

6) Kriteria pengujian:

Jika Lo < Ltabel maka sampel berdistribusi Normal

Jika Lo > Ltabel maka sampel tidak berdistribusi Normal

b. Uji Homogenitas

Sudjana (2005:250), Uji homogenitas berfungsi untuk mengetahui apakah dua data penelitian memiliki kesamaan varians. Syarat utama pengujian homogenitas apabila kedua data berdistribusi normal. Homogenitas data penelitian dapat diuji dengan membandingkan varians terbesar dengan varians terkecil. Secara rumus dapat ditulis :

$$
F=\frac{\text { Varians terbesar }}{\text { Varians terkecil }}
$$

Kriteria pengujian adalah jika $\mathrm{F}$ hitung lebih kecil dari $\mathrm{F}$ tabel pada taraf signifikan $5 \%$ maka data hasil penelitian homogen.

\section{Uji Hipotesis}

Pengujian hipotesis dilakukan dengan cara Uji kesamaan rata-rata postest (uji $\mathrm{t}$ satu pihak). Uji t satu pihak digunakan untuk mengetahui adanya peningkatan hasil belajar DDK siswa dilihat dari ada tidaknya perbedaan hasil postest siswa pada kedua kelas yaitu kelas Eksperimen dan kelas Kontrol. Pengujian ada tidaknya perbedaan hasil postest siswa digunakan uji t satu pihak (pihak kanan) dengan hipotesis :

$H_{o}: \mu m c \leq \mu_{k}$

$H_{a}: \mu m c>\mu_{k}$ 2005)

Keterangan :

umc : Siswa yang diajarkan dengan ( media crocodile

$\mu k \quad \mathrm{~S}$ : Siswa yang diajarkan dengan ) media gambar di papan tulis

Untuk uji hipotesis digunakan uji $\mathrm{t}$ dengan rumus :

$$
t_{\text {hitung }}=\frac{\mathrm{x}_{1}-\mathrm{X}_{2}}{\sqrt{\frac{\mathrm{s}_{1}^{2}}{\mathrm{n}_{1}}+\frac{\mathrm{s}_{2}^{2}}{\mathrm{n}_{2}}}} \quad \text { (Sudjana, }
$$

2005)

Dimana :

$\bar{X}_{1}$ = Nilai rata-rata hasil belajar siswa kelas Eksperimen

$\bar{X}_{\mathbf{2}}=$ Nilai rata-rata hasil belajar siswa kelas Kontrol

$n_{1}=$ Jumlah siswa kelas Eksperimen

$n_{\mathbf{2}}=$ Jumlah siswa kelas Kontrol $S_{\mathbf{1}}^{\mathbf{2}}=$ Varians nilai hasil belajar siswa kelas Eksperimen

$S_{\mathbf{z}}^{\mathbf{z}}=$ Varians nilai hasil belajar siswa kelas Kontrol 1

Untuk kriteria pengujian tolak hipotesis $\mathrm{H}_{0}$ jika :

$$
t^{\prime} \geq \frac{w_{1} t_{1}+w_{2} t_{2}}{w_{1}+w_{2}}
$$


Pengaruh Penggunaan Media Pembelajaran Terhadap Hasil Belajar Dasar-Dasar Kelistrikan (DDK) Kelas X Program Keahlian Teknik Instalasi Tenaga Listrik (TITL) SMK Negeri 1 Lubuk Pakam

Dan terima $\mathrm{H}_{0}, \quad$ jika terjadi
sebaliknya, dengan $\mathrm{w}_{1}=s_{1}^{2} / n_{1}, \mathrm{w}_{2}=$
$s_{2}^{2} / n_{2}, \mathrm{t}_{1}=\mathrm{t}_{\text {tabel }},\left(\mathrm{n} 1-{ }_{1}\right)$ dan $\mathrm{t}_{2}=\mathrm{t}_{\text {tabel, (n2- }}$
1).
Dengan taraf $\alpha=0,05$ dan $\alpha_{1=} \alpha_{2}$, maka kriteria pengujian hipotesis adalah: terima Ho jika $t_{\text {hitung }}<t_{\text {tabel }}$ dan tolak Ho jika t mempunyai harga lain. Derajat kebebasan untuk daftar distribusi $\mathrm{t}$ ialah $\left(\mathrm{n}_{1}+\mathrm{n}_{2}-2\right)$ dengan peluang $(1-\alpha)$.

Jika analisis data menunjukkan $t_{\text {hitung }}$ $>t_{\text {tabel }}$ atau nilai $t_{\text {hitung }}$ yang diperoleh lebih dari nilai $t_{\text {tabel}}$, maka hipotesis Ho ditolak dan diterima Ha. Dapat diambil kesimpulan hasil belajar DDK siswa pada kelas Eksperimen lebih tinggi dibandingkan hasil belajar siswa pada kelas Kontrol, maka media pembelajaran crocodile dikatakan berpengaruh terhadap hasil belajar siswa.

Untuk pengujian hipotesis, maka dirumuskan sebagai berikut:

$$
\begin{aligned}
& H_{0}: \mu_{A} \leq \mu_{B} \\
& H_{a}: \mu_{A}>\mu_{B}
\end{aligned}
$$

Keterangan :

$\mu_{A}$ : Siswa yang diajarkan dengan media pembelajaran crocodile

$\begin{array}{cl}\mu_{B} \quad \text { : Siswa yang diajarkan dengan } \\ \\ \quad \text { media gambar di papan tulis } \\ >\quad \text { : Tidak terdapat pengaruh } \\ \text { Ho } \quad \text { Terdapat pengaruh } \\ & \text { : Tidak terdapat pengaruh } \\ & \text { hasil belajar DDK antara } \\ & \text { siswa yang diajarkan dengan } \\ & \text { media crocodile dan dengan } \\ & \text { media gambar di papan tulis. } \\ \text { Ha } \quad \text { Terdapat Pengaruh hasil } \\ & \text { belajar DDK siswa yang } \\ & \text { diajarkan dengan media } \\ & \text { crocodile dan dengan media } \\ & \text { gambar di papan tulis. }\end{array}$

\section{BAB IV}

HASIL PENELITIAN DAN PEMBAHASAN

\section{A. Hasil Penelitian}

\section{Deskripsi Hasil Belajar}

Berdasarkan hasil belajar siswa yang diperoleh pada penelitian dan setelah ditabulasikan maka diperoleh rata-rata, standar deviasi, dan varians dari data posttest baik dari kelas eksperimen maupun kelas kontrol seperti Tabel 4.1 di bawah ini.

Tabel 4.1. Rata-Rata, Standar Deviasi, Dan

\begin{tabular}{|c|c|c|c|}
\hline Kelas & $\begin{array}{c}\text { Nila } \\
\text { Rata- } \\
\text { rata } \\
\text { Posttes } \\
\mathrm{t}\end{array}$ & $\begin{array}{c}\text { Standa } \\
\mathrm{r} \\
\text { Devias } \\
\mathrm{i}\end{array}$ & $\begin{array}{c}\text { Varian } \\
\mathrm{s}\end{array}$ \\
\hline $\begin{array}{c}\text { Eksperi } \\
\text { men }\end{array}$ & 24,10 & 3,53 & 12,48 \\
\hline Kontrol & 20,74 & 3,175 & 10,08 \\
\hline
\end{tabular}

Berdasarkan tabel 4.1. diperoleh ratarata nilai posttest kelas eksperimen sebesar 24,10 . Berarti nilai rata-rata yang didapat melebihi dari nilai ideal yaitu 15. Dengan nilai tertinggi 30 dan nilai terendah 17 , standar deviasi sebesar 3,53 serta varians sebesar 12,48 . Sedangkan rata - rata nilai posttest untuk kelas kontrol sebesar 20,74 melebihi dari nilai ideal yaitu 15. Dengan nilai tertinggi 26 dan nilai terendah 14 , standar deviasi sebesar 3,175 serta varians sebesar 10,08.

a. Hasil Belajar Dasar-Dasar Kelistrikan (DDK) pada Siswa yang diajar dengan Menggunakan Media Pembelajaran Crocodile.

Berdasarkan tes hasil belajar yang diberikan setelah proses pemberian perlakuan dengan Media Crocodile diperoleh rata-rata skor $=24,10 ;$ Varians $=$ 12,48; Standar Deviasi $=3,53$; skor tertinggi $=30$; skor terendah $=17$ dengan jumlah sample $=30$ orang. Dengan menggunakan teknik sturges didapatkan banyak kelas 5 dan panjang kelas 3, maka daftar distribusi frekuensi mengenai hasil belajar yang diajar dengan media crocodile dapat dilihat pada tabel 4.2 dibawah ini:

Tabel 4.2. Distribusi Frekuensi Skor hasil belajar siswa yang diajar dengan menggunakan media crocodile

\begin{tabular}{|c|c|c|c|}
\hline Kelas & Interval & Fo & Fr \\
\hline 1 & $17-19$ & 3 & 10 \\
\hline 2 & $20-22$ & 7 & 23,3333 \\
\hline 3 & $23-25$ & 7 & 23,3333 \\
\hline 4 & $26-28$ & 10 & 33,3333 \\
\hline 5 & $29-31$ & 3 & 10 \\
\hline
\end{tabular}






Gambar 4.1 Histogram Hasil Belajar siswa yang diaja dengan menggunakan media crocodile

b. Hasil Belajar Dasar-Dasar Kelistrikan pada Siswa Yang Diajar Dengan Menggunakan Media Gambar Dipapan Tulis

Berdasarkan tes hasil belajar yang diberikan setelah proses pemberian perlakuan dengan menggunakan media gambar di papan tulis diperoleh rata-rata skor $=20,74 ;$ varians $=10,08 ;$ standar deviasi $=3,175$, skor tertinggi $=27$ dan skor terendah $=14$ dengan jumlah sampel 35 siswa. Dengan menggunakan teknik Sturges didapatkan banyak kelas 7 dan panjang kelas 2, maka daftar distribusi frekuensi mengenai hasil belajar yang diajar dengan media gambar dipapan tulis dapat dilihat pada Tabel 4.3 dibawah ini :

Tabel 4.3. Distribusi Frekuensi Skor Hasil Belajar Siswa Yang Diajar Dengan Menggunakan Media Gambar Papan tulis

\begin{tabular}{|c|c|c|c|}
\hline Kelas & Interval & Fo & Fr \\
\hline 1 & $14-15$ & 1 & 2,85714 \\
\hline 2 & $16-17$ & 4 & 11,4286 \\
\hline 3 & $18-19$ & 10 & 28,5714 \\
\hline 4 & $20-21$ & 5 & 14,2857 \\
\hline 5 & $22-23$ & 7 & 20 \\
\hline 6 & $24-25$ & 6 & 17,1429 \\
\hline 7 & $26-27$ & 2 & 5,71429 \\
\hline \multicolumn{2}{|c|}{ Jumlah } & 35 & 100 \\
\hline
\end{tabular}

\section{Distribusi Frekuensi}

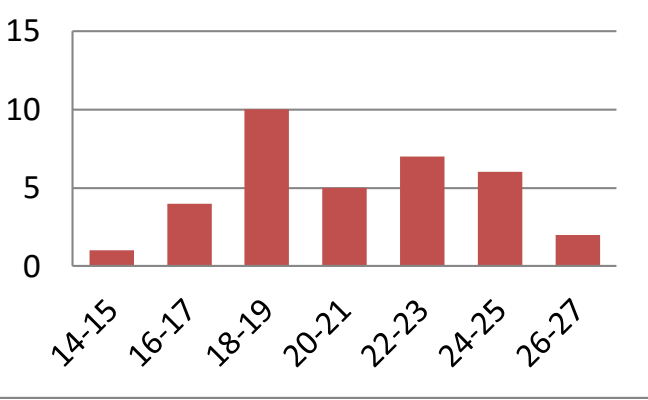

Gambar 4.2 Histogram Hasil Belajar siswa yang diajar dengan menggunakan media gambar dipapan tulis

\section{Uji Persyaratan Analisis Data}

Sebelum sampel diberi perlakuan terlebih dahulu dilakukan uji normalitas dan uji homogenitas dengan menggunakan data posttest (pada lampiran ) untuk lebih jelas diuraikan sebagai berikut :

\section{a. Uji Normalitas}

Uji normalitas dimaksudkan untuk mengetahui apakah kedua sampel berdistribusi normal atau tidak. Dari lampiran uji normalitas diketahui harga L untuk uji Liliefors dengan $\alpha=$ 0,05. Kriteria pengujian jika $\mathrm{L}_{\text {hitung }}<\mathrm{L}_{\text {tabel }}$ maka data berdistribusi normal. Data hasil pengujian disajikan dalam tabel 4.4 di bawah ini.

Tabel 4.4. Ringkasan Uji Normalitas

\begin{tabular}{|c|c|c|c|c|c|}
\hline No & $\begin{array}{c}\text { Dat } \\
\mathbf{a}\end{array}$ & Kelas & $\mathbf{L}_{t}$ & $\mathbf{L}_{\mathbf{h}}$ & $\begin{array}{c}\text { Ke } \\
\text { ter } \\
\text { an } \\
\text { ga } \\
\text { n }\end{array}$ \\
\hline \multirow[t]{2}{*}{1} & \multirow{2}{*}{$\begin{array}{c}\text { Pos } \\
\text { ttes } \\
\mathrm{t}\end{array}$} & Ekperimen & 0,1621 & $\begin{array}{l}0,1 \\
103\end{array}$ & $\begin{array}{c}\text { No } \\
\text { rm } \\
\text { al }\end{array}$ \\
\hline & & Kontrol & 0,1501 & $\begin{array}{l}0,1 \\
339\end{array}$ & $\begin{array}{c}\text { No } \\
\text { rm } \\
\text { al }\end{array}$ \\
\hline
\end{tabular}

Dari tabel di atas diketahui data posttest berdistribusi normal. Hal ini terlihat dari harga $\mathrm{L}_{\text {hitung }}$ tidak melebihi $\mathrm{L}_{\text {tabel }}$ yang mengindikasikan bahwa data berdistribusi normal.

\section{b. Uji Homogenitas}

Uji homogenitas dimaksudkan untuk mengetahui apakah kedua sampel berasal dari populasi yang homogen atau tidak. Dari lampiran uji homogenitas diketahui harga harga $\mathrm{F}$ untuk uji homogenitas dengan $\alpha=0,05$. Kriteria pengujian adalah jika $F_{\text {hitung }}<\mathrm{F}_{\text {tabel }}$ 
Pengaruh Penggunaan Media Pembelajaran Terhadap Hasil Belajar Dasar-Dasar Kelistrikan (DDK) Kelas X Program Keahlian Teknik Instalasi Tenaga Listrik (TITL) SMK Negeri 1 Lubuk Pakam

maka data berdistrbusi normal. Data hasil pengujian disajikan dalam tabel 4.5. di bawah ini.

Tabel 4.5. Ringkasan Uji Homogenitas

\begin{tabular}{|c|c|c|c|c|c|c|}
\hline No & $\begin{array}{c}\text { Dat } \\
\mathbf{a}\end{array}$ & Kelas & $\begin{array}{l}\text { Var } \\
\text { ians }\end{array}$ & $\mathbf{F}_{\mathbf{t}}$ & $F_{h}$ & $\begin{array}{c}\text { Keter } \\
\text { anga } \\
\text { n }\end{array}$ \\
\hline \multirow[t]{2}{*}{1} & \multirow{2}{*}{$\begin{array}{c}\text { Pos } \\
\text { ttes } \\
t\end{array}$} & $\begin{array}{c}\text { Ekperi } \\
\text { men }\end{array}$ & $\begin{array}{c}12,4 \\
8\end{array}$ & \multirow[t]{2}{*}{$\begin{array}{l}1, \\
74\end{array}$} & \multirow[t]{2}{*}{$\begin{array}{l}1, \\
24\end{array}$} & \multirow[t]{2}{*}{$\begin{array}{l}\text { Hom } \\
\text { gen }\end{array}$} \\
\hline & & Kontrol & $\begin{array}{c}10,0 \\
8\end{array}$ & & & \\
\hline
\end{tabular}

Dari tabel di atas diketahui bahwa sampel yang berupa kelas eksperimen dan kelas kontrol berasal dari populasi yang homogen. Hal ini terlihat dari harga $F_{\text {hitung }}$ tidak melebihi $F_{\text {tabel }}$ yang mengindikasikan bahwa sampel berasal dari populasi yang homogen.

\section{Uji Hipotesis}

Setelah dilakukan uji normalitas dan uji homogenitas diketahui bahwa kedua sampel adalah berdistribusi normal dan memiliki varians yang homogen, maka selanjutnya dilakukan pengujian hipotesis. Dalam penggunaan uji hipotesis penelitian ini digunakan uji beda (uji t). Adapun pengujian hipotesis ini dilakukan untuk membedakan rata - rata hasil belajar posttest siswa kelas eksperimen dan kelas kontrol dan untuk mengetahui Ada Pengaruh penggunaan media crocodile terhadap hasil belajar dasar-dasar kelistrikan pada siswa kelas X Program Keahlian Teknik Instalasi Tenaga Listrik SMK Negeri 1 Lubuk Pakam. Adapun hipotesis yang akan diuji dalam penelitian ini adalah :

Hipotesis alternatif $\left(\mathrm{H}_{\mathrm{a}}\right)$ : Terdapat Pengaruh yang Signifikan Dari Penggunaan Media Crocodile Terhadap Hasil Belajar Dasar-Dasar Kelistrikan pada Siswa Kelas X Program Keahlian Teknik Instalasi Tenaga Listrik SMK Negeri 1 Lubuk Pakam.

Hasil pengujian hipotesis pada taraf signifikan 0,05 dan $\mathrm{dk}=30+35-2=63$ berada diantara dk $60 \mathrm{dan} \mathrm{dk} 120$, diperoleh $t_{\text {hitung }}=4,004$ sedangkan $t_{\text {tabel }}=1,67035$, $t_{\text {hitung }}>$ $\mathrm{t}_{\text {tabel }}$ berarti $\mathrm{H}_{\mathrm{a}}$ diterima. Dapat disimpulkan ada pengaruh penggunaan media crocodile terhadap hasil belajar dasar-dasar kelistrikan pada siswa kelas X Program Keahlian Teknik Instalasi Tenaga Listrik SMK Negeri 1 Lubuk Pakam, secara ringkas hasil perhitungan uji hipotesis dinyatakan dalam tabel 4.6.

Tabel 4.6. Ringkasan Uji Hipotesis

\begin{tabular}{|c|c|c|c|c|c|}
\hline No & Data & Kelas & $\mathbf{t}_{\mathbf{h}}$ & $\begin{array}{c}\mathbf{T}_{\text {tab }} \\
\text { el }\end{array}$ & $\begin{array}{c}\text { Keter } \\
\text { anga } \\
\mathbf{n}\end{array}$ \\
\hline
\end{tabular}

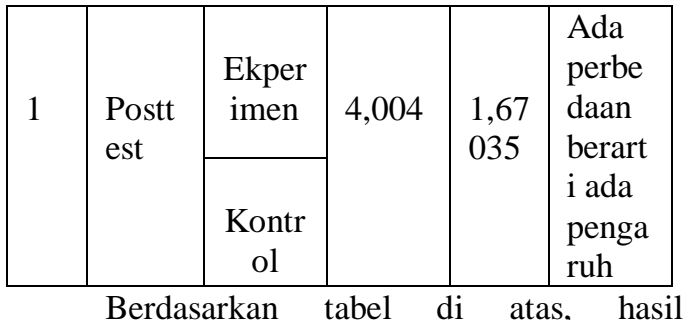

perhitungan uji perbedaan nilai rata - rata 1,67035, maka terima $\mathrm{H}_{a}$, sehingga diperoleh kesimpulan bahwa terdapat Pengaruh Penggunaan Media Crocodile Terhadap Hasil Belajar Dasar-Dasar Kelistrikan pada Siswa Kelas X Program Keahlian Teknik Instalasi Tenaga Listrik SMK Negeri 1 Lubuk Pakam.

\section{B. PEMBAHASAN}

Sebelum pembelajaran, dilakukan pretest untuk mengetahui sampel berdistribusi normal dan homogen statusnya. Kemudian siswa diajarkan dengan menggunakan media crocodile (kelas eksperimen) dan media gambar dipapan tulis (kelas kontrol). Setelah pembelajaran dilakukan maka siswa diberi posttest untuk mengetahui hasil belajar siswa.

Dari hasil penelitian didapat hasil $\mathrm{X}_{1}=$ 24,10 untuk kelas eksperimen dan $X_{2}=20,74$ untuk kelas kontrol. Setelah dilakukan analisis statistik terhadap hasil belajar siswa pada kelas eksperimen dan kontrol dengan menggunakan uji $\mathrm{t}$. Dari daftar distribusi $\mathrm{t}$ didapat $\mathrm{t}_{\text {hitung }}=$ 4,004 sedangkan $t_{\text {tabel }}=1,67035$. Karena $t_{\text {hitung }}$ $>t_{\text {tabel, }}$ maka Ha diterima. Ini membuktikan hasil belajar siswa yang menggunakan media crocodile lebih tinggi dari pada media gambar dipapan tulis, sehingga dapat disimpulkan bahwa terdapat Pengaruh Penggunaan Media Crocodile Terhadap Hasil Belajar Dasar-Dasar Kelistrikan pada Siswa Kelas X Program Keahlian Teknik Instalasi Tenaga Listrik SMK Negeri 1 Lubuk Pakam.

Pada proses pembelajaran di kelas, kesamaan antara kelas eksperimen dan kelas kontrol adalah memperoleh pembelajaran dengan metode diskusi informasi, serta tanya jawab. Perbedaannya hanya perlakuan yang diberikan yaitu media pembelajaran yang digunakan. Pada kelas eksperimen, menggunakan media crocodile, sedangkan pada kelas kontrol menggunakan media gambar dipapan tulis.

Pada akhir pembelajaran dilakukan tes yang hasilnya di analisis untuk mengetahui perbedaan antar kedua kelas. Analisis tahap akhir menunjukkan data hasil belajar kelas eksperimen dan kelas kontrol berdistribusi normal karena $\mathrm{L}_{\text {hitung }}$ untuk setiap data kurang dari $\mathrm{L}_{\text {tabel. }}$ Hasil uji kesamaan varians data hasil belajar kelas eksperimen dan kelas kontrol 
Pengaruh Penggunaan Media Pembelajaran Terhadap Hasil Belajar Dasar-Dasar Kelistrikan (DDK) Kelas X Program Keahlian Teknik Instalasi Tenaga Listrik (TITL) SMK Negeri 1 Lubuk Pakam

diperoleh $F_{\text {hitung }}(1,24)<F_{\text {tabel }}(1,74)$ sehingga dapat disimpulkan bahwa kedua kelompok mempunyai variansi yang sama (homogen).

Dari hasil perhitungan rata-rata nilai postest dapat dilihat bahwa rata - rata hasil belajar kelas eksperimen $(24,10)$ lebih tinggi dari kelas kontrol $(20,74)$. Perbedaan hasil belajar yang terjadi disebabkan karena perbedaan media pembelajaran.

Pada kelas eksperimen, menggunakan media crocodile sebagai alat bantu untuk memperjelas bahan pelajaran pada saat guru menyampaikan pelajaran. Sedangkan pada kelas kontrol menggunakan media gambar dipapan tulis. Guru sebagai subjek yang aktif dan siswa sebagai objek yang pasif, sehingga dalam menyampaikan materi guru kepada siswa bersifat abstrak dan tereoritis.

Berdasarkan uji hipotesis yang telah dilakukan, diperoleh $\mathrm{t}_{\text {hitung }}=4,004$ sedangkan $\mathrm{t}_{\text {table }}=1,667035$. Karena $\mathrm{t}_{\text {hitung }}>\mathrm{t}_{\text {tabel }}$ atau berada pada daerah penerimaan $\mathrm{Ha}$ maka dapat disimpulkan bahwa terdapat Pengaruh Penggunaan Media Crocodile Terhadap Hasil Belajar Dasar-Dasar Kelistrikan pada Siswa Kelas X Program Keahlian Teknik Instalasi Tenaga Listrik SMK Negeri 1 Lubuk Pakam.

\section{BAB V \\ KESIMPULAN, IMPLIKASI DAN SARAN}

\section{A. Kesimpulan}

Berdasarkan hasil penelitian yang diuraikan pada BAB IV, maka diambil kesimpulan sebagai berikut:

1. Nilai rata-rata hasil belajar siswa pada kompetensi dasar-dasar kelistrikan dengan menggunakan media crocodile pada siswa kelas $\mathrm{X}$ program keahlian Teknik Instalasi Tenaga Listrik SMK Negeri 1 Lubuk Pakam yaitu 24,10.

2. Nilai rata-rata hasil belajar siswa pada kompetensi dasar-dasar kelistrikan dengan menggunakan media gambar dipapan tulis pada siswa kelas $\mathrm{X}$ program keahlian Teknik Instalasi Tenaga Listrik SMK Negeri 1 Lubuk Pakam yaitu 20.74 .

3. Nilai rata-rata hasil belajar siswa pada kompetensi dasar-dasar Kelistrikan (DDK) yang diajarkan dengan menggunakan media crocodile lebih tinggi yaitu 24,10 daripada siswa yang diajarkan dengan menggunakan media gambar dipapan tulis yaitu 20,74 kelas X Program Keahlian Teknik Instalasi Tenaga Listrik SMK Negeri 1 Lubuk
Pakam. Dimana $F_{\text {hitung }}=1,24<\mathrm{F}_{\text {tabel }}=$ 1,74 .

\section{B. Implikasi}

Berdasarkan hasil penelitian dan kesimpulan penelitian maka diberikan implikasi sebagai berikut :

1. Jika Media Crocodile diterapkan oleh guru dalam kegiaatan belajar mengajar, maka hasil belajar dasar-dasar kelistrikan pada siswa kelas X SMK Negeri 1 Lubuk Pakam akan semakin meningkat.

2. Jika Media gambar dipapan tulis diterapkan oleh guru dalam kegiatan belajar mengajar maka perlu perhatian yang lebih kepada siswa agar siswa aktif dalam kegiatan belajar mengajar sehingga hasil belajar semakin meningkat.

\section{Saran}

Berdasarkan hasil analisis data dan kesimpulan yang dikemukakan sebelumnya, maka disarankan hal-hal sebagai berikut :

1. Hasil penelitian ini telah menunjukkan bahwa media crocodile memberikan pengaruh yang lebih tinggi terhadap hasil belajar jika dibandingkan dengan media gambar dipapan tulis. Jadi disarankan agar para guru dapat menerapkan media crocodile pada kegiatan belajar untuk meningkatkan hasil belajar siswa siswa seperti yang ditunjukkan oleh hasil belajar dasar-dasar kelistrikan.

2. Kepada para peneliti yang ingin mengkaji pengaruh media pembelajaran terhadap hasil belajar, disarankan untuk meneliti media pembelajaran apa yang lebih unggul untuk meningkatkan hasil belajar siswa.

\section{DAFTAR PUSTAKA}

Arikunto, S. 2011. Dasar-Dasar Evaluasi Pendidikan. Jakarta: Bumi Aksara. 2005. Manajemen Penelitian. Jakarta: Rineka Cipta.

Asi, Tiur. 2012. Evaluasi Belajar. Jakarta: Halaman Moeka.

Daryanto. 2010. Belajar dan Mengajar. Bandung: Yrama Widya.

Dimiati. 2002. Belajar dan Pembelajaran. Jakarta: Rineka Cipta.

Hamalik, Oemar. 2001. Proses Belajar Mengajar. Jakarta: PT. Bumi Aksara.

Indriati. 2012. Penerapan Science Edutainment. Jakarta. 
Pengaruh Penggunaan Media Pembelajaran Terhadap Hasil Belajar Dasar-Dasar Kelistrikan (DDK) Kelas X Program Keahlian Teknik Instalasi Tenaga Listrik (TITL) SMK Negeri 1 Lubuk Pakam

Istarani. 2012. 58 Model Pembelajaran Inovatif. Medan: Media Persada.

Lodran, Luka., Matev, Poljan. Tanpa Tahun. Crocodile Technology 609. Terjemahan M. Ichsan dan Azri syafwatul. 2014. Medan.

Purwadi, Heri. 2012. Penerapan model pembelajaran visual berbasis software Crocodile Physic. Purworejo.

Purwanto, Ngalim. 2009. Prinsip-prinsip dan Teknik Evaluasi Pengajaran. Bandung: PT. Remaja Rosdakarya.

Slameto. 2010. Belajar dan Faktor-faktor yang Mempengaruhinya. Jakarta: Rineka Cipta

Sudjana. 2005. Metode Statistik. Bandung: Tarsito.

Sudjono, Anas. 2009. Pengantar Evaluasi Pendidikan. Jakarta: PT Raja Grafindo Persada.

Sukardi. 2008. Evaluasi Pendidikan. Bandung: Bumi Aksara.

Sukisno, Eddi. 2013. Implementasi Media Crocodile Physic. Malang. Universitas Malang.

Surapranata, Sumarna. 2004. Analisis, Validitas, Reliabilitas, dan Interpretasi Hasil Tes. Bandung: PT Remaja Rosdakarya.

Uno, Hamzah. 2008. Perencanaan Pembelajaran. Jakarta: Bumi Aksara.

Wakhid Akhdinirwanto. 2010. Motivasi belajar dengan menggunakan media Crocodile Physic. Bandung. Universitas tidak dipublikasi.

Winarti, dan Ishafit. 2007. Pemanfaatan

Perangkat Lunak Video Analisis Tracker Dalam Eksperimen Fisika. Kota dan tempat perguruan tinggi tidak dipublikasi. 